\section{EXPERT OPINION}

1. Introduction

2. $\alpha$-Subtype-selective ligands

3. $\mathrm{GABA}_{\mathrm{A}}$ receptor modulators

4. Labeled compounds

5. Patents of natural products and derivatives

6. Expert opinion

\title{
Benzodiazepine receptor ligands: a patent review (2006 - 2012)
}

\author{
Gabriella Guerrini ${ }^{\dagger}$ \& Giovanna Ciciani \\ Dipartimento di Neuroscienze, Psicologia, Area del Farmaco e Salute del Bambino, \\ NEUROFARBA - "Sezione di Farmaceutica e Nutraceutica" Università degli Studi di, \\ Firenze, Italy
}

Introduction: Ligands at the benzodiazepine site of the $\mathrm{GABA}_{\mathrm{A}}$ receptor $\left(G A B A_{A}-R\right)$ act by modulating the effect of GABAA ( $\gamma$-aminobutyric acid). The selective modulator effects of such ligands are related to the $\alpha$-subunits type (i.e., $\alpha 1, \alpha 2, \alpha 3$, and $\alpha 5$ ), being shown that the $\alpha 1$ subunit is associated with sedative, anticonvulsant and amnesic effects; whereas the $\alpha 2$ and $\alpha 3$ subunits mediate anxiolytic and myorelaxant effects. Recently it was shown the involvement of $\alpha 5$ subunit in pain relief, which is involved in cognitive processes of learning and memory.

Areas covered: This review covers patents, published from January 2006 to October 2012, on ligands for the benzodiazepine binding site of the $G A B A_{A}-R s$. Patents filed from different companies and research groups report many series of compounds that may be used in the treatment or prevention of a large variety of neurodegenerative diseases.

Expert opinion: Most patents highlighted that various memory deficits, related to Alzheimer's disease, Down syndrome, mood disorders, schizophrenia, and age-related cognitive impairment may be treated using $\alpha 5$-selective ligands. Other aspects related to the use of allosteric modulators of the $\alpha 7-n A c h R$ and/or $\alpha 5-G A B A_{A}-R$ (dual approach) for alleviating the impaired cognition and the use of $\alpha 2$-selective ligands for pain relief are highlighted, being particularly intriguing as new therapeutic approaches.

Keywords: benzodiazepine receptor ligands, cognitive impairment, GABAA subtype receptor modulators, neurodegenerative diseases, neuropathic pain

Expert Opin. Ther. Patents [Early Online]

\section{Introduction}

The $\mathrm{GABA}_{\mathrm{A}}$ receptors $\left(\mathrm{GABA}_{\mathrm{A}}-\mathrm{Rs}\right)$ are heteropentamer members of the Cysloop ligand-gated ion channel (LGIC) superfamily permeable to chlorine ions. They are composed of two $\alpha$-, two $\beta$-, and one $\gamma$-subunits (despite the 19 total subunits, i.e., $\alpha 1-6, \beta 1-3, \gamma 1-3, \delta, \varepsilon, \tau, \pi$ and $\rho 1-3$, that could arrange in enormous number of theoretical pentameric combinations). Recently, Olsen and Sieghart [1] reported the criteria to establish which $\mathrm{GABA}_{\mathrm{A}}$ subtype receptors are unequivocally identified in the brain and a list of three categories of native receptor subtypes was suggested, as "identified," "existence with probability" and "tentative." Only 9-11 different subtypes were identified in the brain up until now [1], but the list is continuously being updated with new information. However the distribution of the "identified" $\mathrm{GABA}_{\mathrm{A}}-\mathrm{Rs}$ in the brain predicts that the combination $\alpha 1 \beta \gamma 2$ is the most abundant type (60\%), being located in the cortex, hippocampal neurons, thalamus, and cerebellum. The combination $\alpha 2 \beta \gamma 2$ and $\alpha 3 \beta \gamma 2$ are moderately abundant $(10-20 \%)$ and they are found in the hippocampal formation, hypothalamus, and amygdale. Finally, the combination $\alpha 5 \beta \gamma 2$ is expressed in the hippocampus (pyramidal cells), amygdale, and hypothalamus (5\%) [2]. The identity of the $\beta$ subunits in these combinations is lacking and often cannot be determined, because 


\section{Article highlights.}

- Most of the analyzed patents claim that $\mathrm{GABA}_{\mathrm{A}}$ $\alpha 5$ inverse agonists or $\alpha 5$ agonists may be useful for memory therapy associated with neurodegenerative diseases.

- An intriguing aspect that was revealed regards the use of $\alpha 2 / \alpha 3$-selective ligands for the prevention or suppression of neuropathic pain in addition to their anxiolytic effects.

- The use of a dual approach (allosteric modulators of $\alpha 7-n A c h R$ and/or $\left.\alpha 5-G A B A_{A}-R\right)$ is claimed as a therapeutically relevant modality to ameliorate CNS disorders.

- The chemical scaffolds of the claimed drugs show a high degree of heterogeneity and an enhanced flexibility.

- The label strategy is another topic reported in some patents with the aim to obtain a higher metabolic stability or useful diagnostics tools for imaging methods.

This box summarizes key points contained in the article.

of the co-precipitation of all three subunits in immunoprecipitation or electrophysiological studies [3]. However, even if the subunit $\beta 1$ is the least common, the $\beta 2$ is the most abundant and widespread, whereas the $\beta 3$ is more discrete. All $\beta$ isoforms can exist in functional receptors, and usually as one type per pentamer [3]. Subunits $\alpha 4$ and $\alpha 3$ are present in combination with $\beta 2 / 3$ isoforms and with the subunit $\delta$ and represent a minor population of receptors in the striatum and cerebellum [4].

The benzodiazepine site on $\mathrm{GABA}_{\mathrm{A}}-\mathrm{R}$ (alternatively named $\mathrm{GABA}_{\mathrm{A}} / \mathrm{Bz}$ site, $\mathrm{GABA}_{\mathrm{A}}$ subtype receptor, or $\alpha_{n}$-containing $\mathrm{GABA}_{\mathrm{A}}-\mathrm{R}$ basing on the contained $\alpha$ subunit) is one among the numerous "binding sites" in the $G_{A B A}-R$. In fact barbiturates, anesthetics, picrotoxin, neurosteroids, alcohol, and $\mathrm{Zn}^{2+}$ can bind and directly activate or modulate the receptor function [4]. In particular, benzodiazepine $(\mathrm{Bz})$ and nonbenzodiazepine ligands bind the receptor in a site that lies at the interface between the $\alpha / \gamma$ subunit. These ligands act by modulating the effect of GABA ( $\gamma$-aminobutyric acid), by increasing the GABA-evoked chlorine current (agonist, positive allosteric modulators [PAM]) or reducing (inverse agonist, negative allosteric modulators [NAM]) or not influencing the chlorine flux (antagonist). The ability of $\mathrm{Bz}$ ligands to modulate GABA-mediated channel activity depends on the presence of the $\gamma$-subunit in the pentamer, whereas their pharmacological effects are related to the type of the $\alpha$-subunits [5].

The proven clinical efficacy of the classical benzodiazepines (anxiolytic, anticonvulsant, myorelaxant, and hypnotic) is associated with several side effects such as sedation, memory deficit, dependence, abuse liability and withdrawal syndrome upon cessation of therapy [6]. Thus, the achievement of selective pharmacological effects is a challenge for researchers active in this field and a variety of approaches have been used to better understand the role of the different subunits in the physiology and pathophysiology of CNS [5]. The attempt to synthesize novel compounds to define the functions of $\mathrm{GABA}_{\mathrm{A}}-\mathrm{R}$ subtypes met with limited success. The advent of the molecular genetics has delineated new perspectives to define the relationships between the $\alpha$ isoform and the pharmacological effects of the $\mathrm{Bz}$ site ligands [3]. The generation of transgenic mouse (knock-in mouse) with a point mutation at the His residue, with Arg at the $\alpha 1-3,5$ subunits (at position 101 in the $\alpha 1$ - and $\alpha 2$-subunits, and in homologous residues in the $\alpha 3$ - and $\alpha 5$-subunits, respectively) produced $\alpha_{n}$-subtype receptors insensible to diazepam, and permitted to identify the pharmacological activity of the specific mutate subunit [6]. In this way, it was shown that the $\alpha 1$ subunit is associated with the sedative, anticonvulsant and amnesic effects of diazepam. The $\alpha 2$ - and $\alpha 3$-subunits mediate the anxiolytic and myorelaxant effects of diazepam [7], whereas the $\alpha 5$ subunit is involved in cognitive processes of learning and memory [8]. These evidences support the hypothesis that subtype-selectivity can lead to pharmacological selectivity, allowing thus the obtaining of anxioselective drugs devoid of sedative effects, as well as procognitive drugs without anxiogenic or convulsant effects [8]. Further genetic studies have been developed mainly with the aim to individuate new roles of the $\alpha$ subunits and to find novel therapeutic opportunities. The obtained results showed that the $\alpha 2$ subunits are involved in schizophrenia [9,10], depression [11-13] and chronic neuropathic pain [14-21]; the $\alpha 5$ subunits are involved in cognitive deficits related to aging [22] and to the Down syndrome (DS) [23,24]. With the same aims, other strategies based on multi-targeted therapy [25,26] and labeled drugs [27,28] have been used.

For the purpose of the present review, we have considered World, US and EP Patents filed from Companies, Universities and individual authors between January 2006 and October 2012, related to $\mathrm{GABA}_{\mathrm{A}}$ benzodiazepine receptor ligands. The patents were selected from SciFinder data base of Chemical Abstract (C.A.) and from Espacenet and have been grouped according to $\alpha$-subtype-selective ligands, $\mathrm{GABA}_{\mathrm{A}}-\mathrm{R}$ modulators, labeled and natural compounds. In case where in vivo data were not given, the compounds were chosen based on the in vitro data, selecting those compounds that possess the highest affinity value $\left(\mathrm{I} \%, \mathrm{IC}_{50}\right.$ or $\left.K_{\mathrm{i}}\right)$. Otherwise, a description of all pharmacological data (vitro and vivo) was made by the authors of the review.

\section{2. $\alpha$-Subtype-selective ligands}

\subsection{Selective $\alpha 5 \mathrm{GABA}_{\mathrm{A}}$ inverse agonists 2.1.1 New compounds}

Hoffmann-La Roche has filed numerous patent applications in the field of $\alpha 5$-selective $\mathrm{GABA}_{\mathrm{A}}$ ligands. The compounds reported in these patents are useful for neurological disorders and in particular as cognitive enhancers or for therapeutic and/or prophylactic treatment of cognitive disorders such as $A D$. The affinity of these compounds at $G_{A B A}-R$ subtype was measured by competition for $\left[{ }^{3} \mathrm{H}\right]$ flumazenil binding to 
Table 1. A list of the patents and representative compounds (Hoffmann-La Roche).

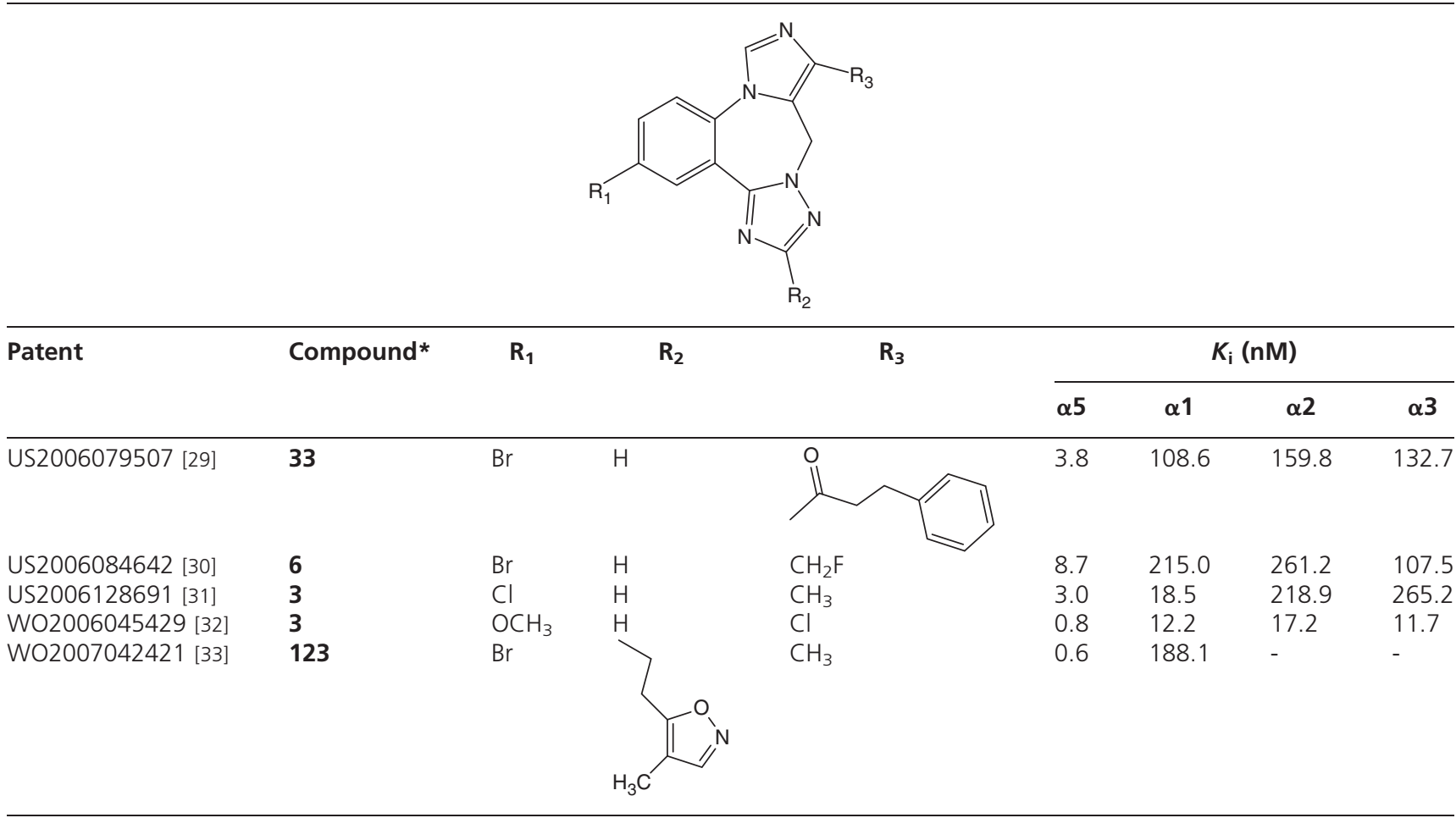

*Original number compound used in the cited patents: selection, made by the authors, of the most representative structures.

HEK293 cells expressing rat (stably transfected) or human (transiently transfected) receptors of the composition $\alpha 1 \beta 3 \gamma 2$, $\alpha 2 \beta 3 \gamma 2, \alpha 3 \beta 3 \gamma 2, \alpha 5 \beta 3 \gamma 2$ [29-55]. In most cases, the compounds showed selectivity for the $\alpha 5$ subunit with respect to $\alpha 1, \alpha 2$ and $\alpha 3$ subunits (Tables 1,2 and 3; binding data to $\alpha 1, \alpha 2$ and $\alpha 3$ subunits are reported when available). This company claimed several chemical series related to imidazo[1,5-a] $[1,2,4]$ triazolo[4,3-d] [1,4]benzodiazepine (Table 1) [29-33], isoxazole (Table 2) [34-53], and triazole derivatives (Table 3) [54,55].

\subsubsection{Known compounds}

Many companies/institutions reported in their application known $\alpha 5$ inverse agonist ligands that, for the sake of clarity, are grouped in Figure 1. The intellectual property is concerned with the pharmacological, preclinic and clinical studies to evaluate the cognitive impairment caused by various diseases (psychiatric pathologies, DS, AS) or conditions (anesthesia, inflammation, etc.).

The Governing Council of the University of Toronto reports [56] methods for the prevention and or treatment of memory impairment (long- and short-term) arising as a consequence of excessive $\mathrm{GABA}_{\mathrm{A}}$-Rs activation. This increased activation can be caused by administration of an anesthetic or by an increase in interleukine-1 $\beta$ (IL-1 $\beta$ ) expression and/ or activity, induced by inflammation or surgery. This patent is concerned with the protocols for planning the pharmacological studies and reports several references for each considered aspect. Data obtained from these studies disclosed the therapeutic utility of the $\alpha 5$ inverse agonists. In particular, L655708 [57] reverses memory deficit after exposure to the anesthetic isoflurane and MRK-016 [58] reverses the memory deficit associated with inflammation, both in young and aging brain.

The invention of Cambridge Enterprise Ltd. [59]. reports to the treatment of impaired cognitive function in patients with psychiatric conditions. In treated patients, the use of flumazenil [60] improved cognitive performance, whereas healthy individuals treated in the same way showed a slightly impaired performance.

The Centre National De la Recherche Scientifique (CNRS) has deposited an application [61] in which the known compounds L655708, MRK-016, RO4938581 [62], $\alpha_{5}$ IA [8], having inverse agonist functional selectivity for $\mathrm{GABA}_{\mathrm{A}}-\mathrm{Rs}$ containing $\alpha_{5}$ subunit, may possess superior efficacy to treat cognitive impairment associated with DS. This was evaluated by in vitro and in vivo tests on Ts65Dn mice, a murine model of DS.

The Board of Trustees of the Leland Stanford Junior University [63] reported methods for improving cognitive functions by administration of negative $\mathrm{GABA}_{\mathrm{A}}-\mathrm{R}$ modulators $\alpha_{5} \mathrm{IA}$, RO4938581, RO4882224 [62], and $\mathrm{GABA}_{\mathrm{A}}-\mathrm{R}$ antagonists, as bilobalide, ginkgolide $\mathrm{B}$ and picrotoxine. The methods provided in this application consisted in the administration of therapeutically effective doses of selected compounds so that the peak concentration occurred when the subject was asleep.

Wisys Technology Foundation in the Patent US7595395 [64] claimed pharmacological methods for the prevention and/or 


\section{G. Guerrini \& G. Ciciani}

Table 2. A list of the patents and representative compounds (Hoffmann-La Roche).

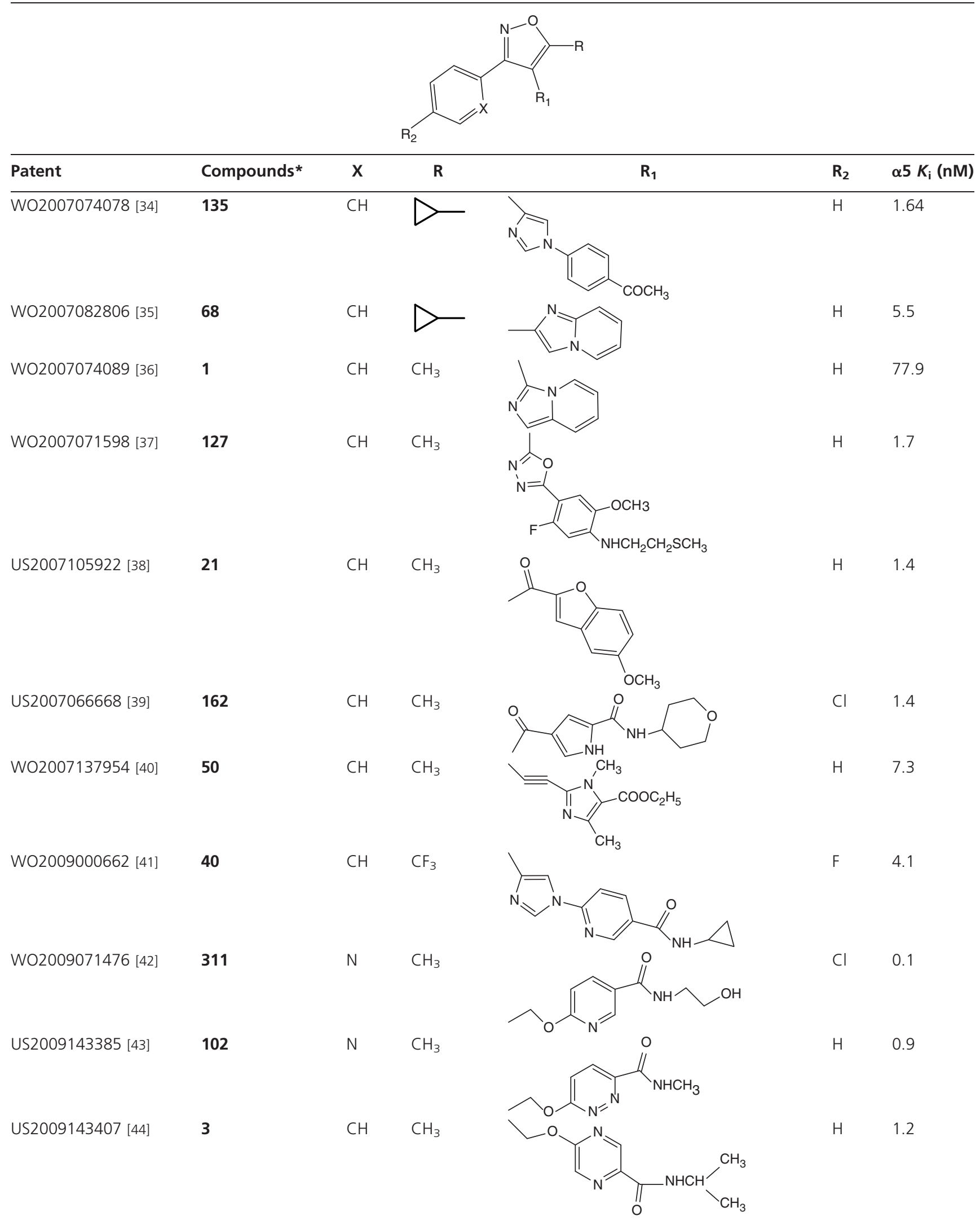

*Original number compound used in the cited patents: selection, made by the authors, of the most representative structures. ${ }^{\ddagger}$ n-butyl is the substituent in 3-position of isoxazole. 
Table 2. A list of the patents and representative compounds (Hoffmann-La Roche) (continued).

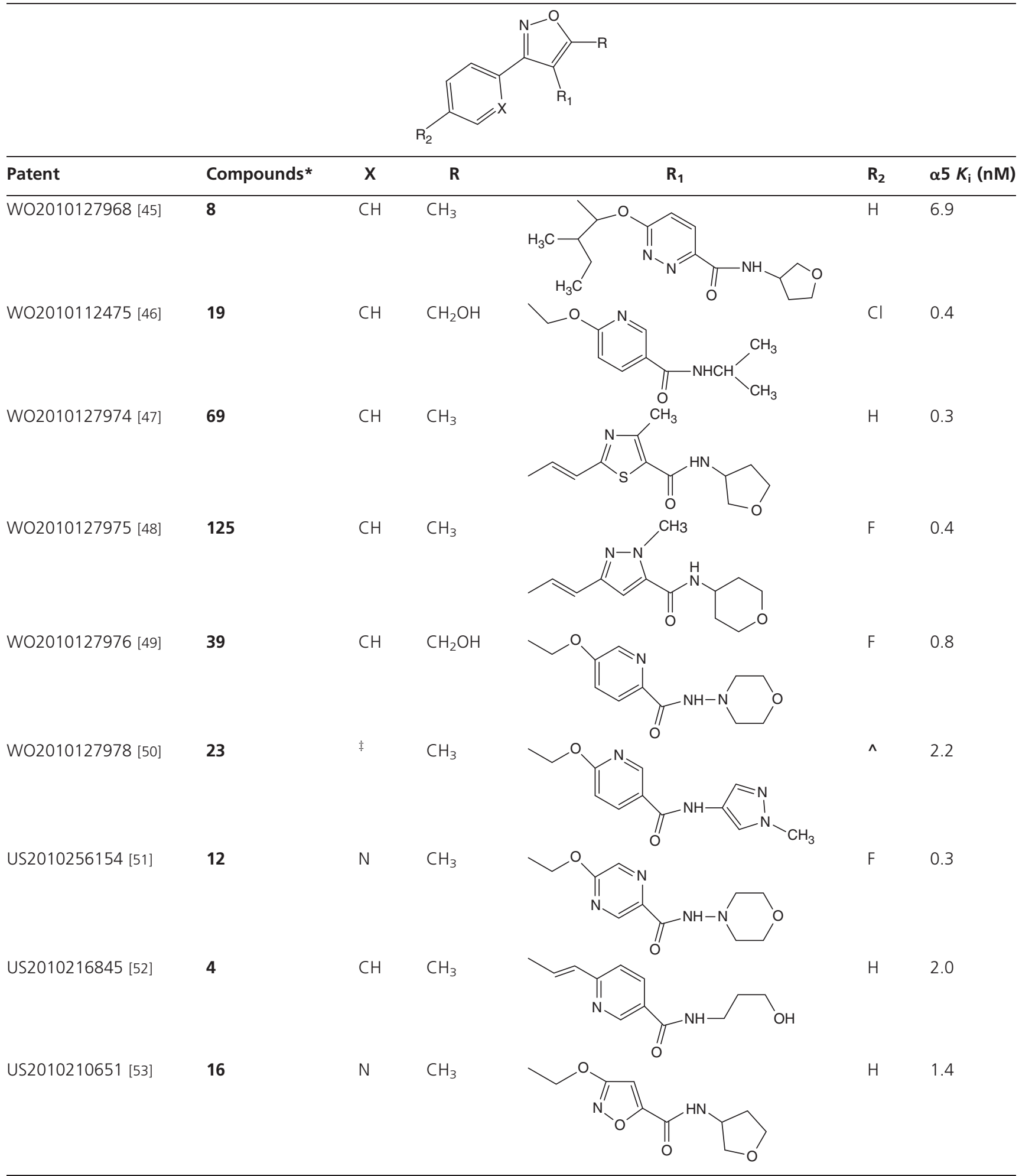

*Original number compound used in the cited patents: selection, made by the authors, of the most representative structures.

${ }_{n}$-butyl is the substituent in 3-position of isoxazole. 


\section{G. Guerrini \& G. Ciciani}

Table 3. A list of the patents and representative compounds (Hoffmann-La Roche).

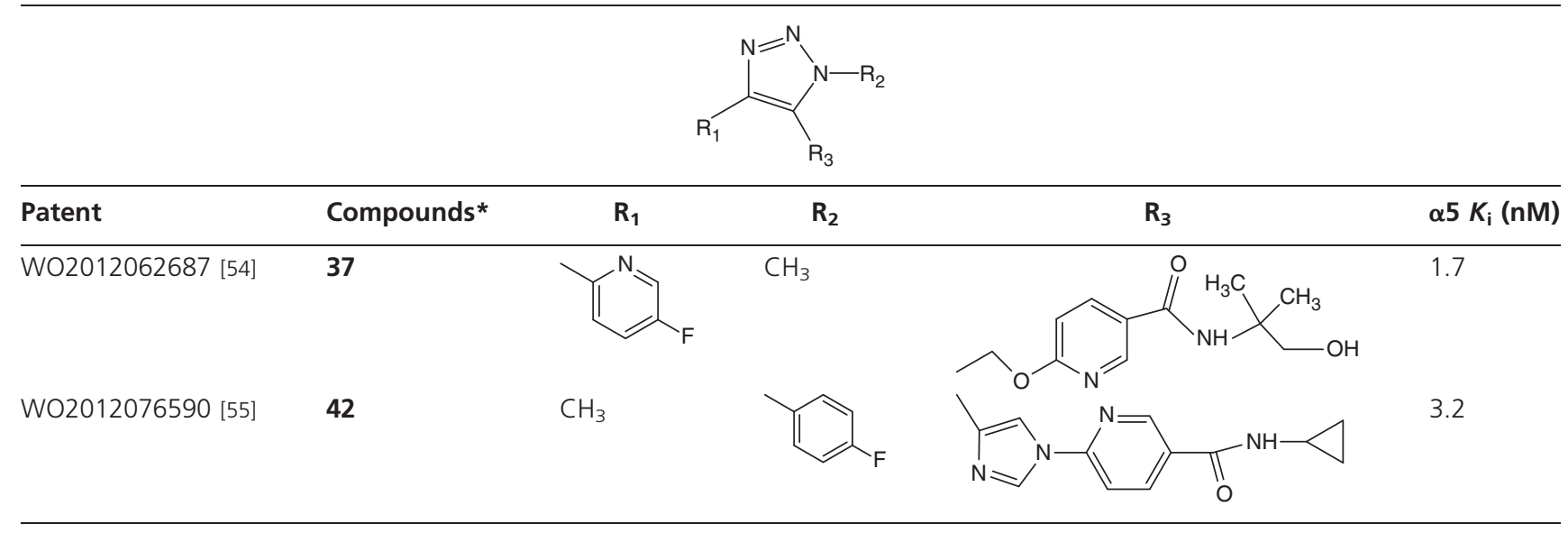

*Original number compound used in the cited patents: selection, made by the authors, of the most representative structures.<smiles>CCOC(=O)c1ncn2c1[C@@]1(CCC2)[C@H]2CCCN1C(=O)c1cc(OC)ccc12</smiles>

L655708

MRK-016<smiles>CCOC(=O)c1ncn2c1CN(C)C(=O)c1cc(F)ccc1-2</smiles>

Flumazenil

WO2012051707 (The Governing Council of The University of Toronto) [56] WO2009016329 (Cambridge Enterprise Ltd.) [59] WO2011024115 (Centre National de la Recherche Scientifique-CNRS) [62]<smiles>FC(F)c1ncn2c1Cn1ncnc1-c1cc(Br)ccc1-2</smiles>

R04938581<smiles>Cc1cc(-c2nnc3c4ccccc4c(OCc4cn(C)nn4)nn23)no1</smiles>

$\alpha 5 \mathrm{~A}$<smiles>Clc1ccc2c(c1)-c1ncnn1Cc1c(Cl)ncn1-2</smiles>

R04882224

WO2011024115 (Centre National de la Recherche Scientifique-CNRS) [62] US20121574445 (The Board of Trustees of the Leland Stanford University) [63]

Figure 1. Structures of known $\alpha 5$ inverse agonists.

treatment of memory deficit. Among the drugs/compounds used in this patent were the $\alpha-5$ inverse agonists PWZ029 [65] and XLi356 (Figure 2) [66]. From a full panel of receptor binding was observed that XLi356 does not bind to other types of receptors and, with PWZ029, were found to reverse scopolamine-induced memory deficit $(1 \mathrm{mg} / \mathrm{kg})$ in mice at the dose of $10 \mathrm{mg} / \mathrm{kg}$. XLi356 and PWZ029 were not able to reverse audio cued memory (amygdale-driven) suggesting that the 
<smiles>COCc1ncn2c1CN(C)C(=O)c1cc(Cl)ccc1-2</smiles>

PWZ-029 $K_{\mathrm{i}}(\mathrm{nM}) \alpha 5=38.8 ; \alpha 1 / \alpha 2 / \alpha 3=300$

US7595395 (Wisys Technology Foundation) [64] US20100130479 (Cook) [67]

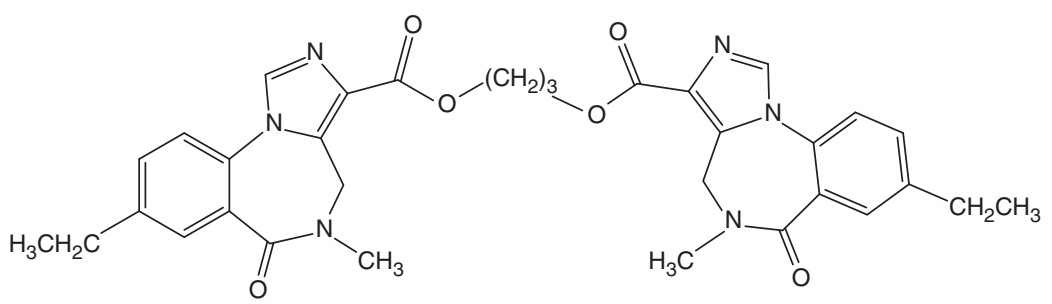

XLi356 $K_{\mathrm{i}}(\mathrm{nM}) \alpha 5=107 ; \alpha 1 / \alpha 2>2000 ; \alpha 3=\mathrm{NT}$

US7595395 (Wisys Technology Foundation) [64]

Figure 2. Examples of known $\alpha 5$ inverse agonists claimed by Wisys Technology Foundation and James Cook.<smiles>Fc1ccc(F)c(-c2nnc3ccc(-c4ccc5[nH]ccc5c4)nn23)c1</smiles>

Example 1 NAM $\alpha 5$ GABA $_{A}-R ;$ PAM $\alpha 7$ AchR

WO20100104843 (The Regents of the University of California) [68]

Figure 3. Example of compound claimed by The Regents of the University of California.

effects of these compounds may be mediate through $\alpha 5$ receptors located in the hippocampus (highly associated with contextual memory).

This patent has been continuing-in-part of patent application US20100130479 by James Cook [67] in which the compound PWZ029, already studied for its cognitive enhancing effect in rodents, was evaluated as cognitive enhancer in a test of "executive function" in monkeys (Object Retrieval with Detours [ORD]).

\subsection{Selective $\alpha 5 \mathrm{GABA}_{\mathrm{A}}$ inverse agonists and $\alpha 7 \mathrm{nACh}$ agonists}

The Regents of the University of California, taking in account the validity of the multi-targeted therapy, presented an invention [68] of dual compounds as $\alpha 5 \mathrm{GABA}_{\mathrm{A}}-\mathrm{Rs} \mathrm{NAM}$ and $\alpha 7 \mathrm{nAChRs}$ PAM (Figure 3). Electrophysiological methods were reported: several compounds were found to have maximum positive modulation at $\alpha 7 \mathrm{nAChRs}$ greater than $500 \%$ (till $1000 \%$ ) at $10 \mu \mathrm{M}$. Other compounds showed maximum negative modulation of $\alpha 5 \mathrm{GABA}_{\mathrm{A}}$-Rs from 5 to $50 \%$ at
$10 \mu \mathrm{M}$. Behavioral tests were performed to evaluate the effect on memory: the compounds of the invention exhibited activity in the radial arm maze paradigm in a range between 0.1 and $10 \mathrm{mg} / \mathrm{kg}$ i.p. The tested compounds did not disrupt rotarod performance, thus the possible CNS-depressant effect being excluded.

\subsection{Selective $\alpha 5$ GABA $_{A}$ agonists}

Based on studies [69] that linked the age-related cognitive decline and schizophrenia to a reduction of hippocampal expression of $\alpha 5$ subunit of the $\mathrm{GABA}_{\mathrm{A}}-\mathrm{R}$, it has been suggested the usefulness of $\alpha 5$-agonists in the treatment of CNS disorders. Agenebio, Inc. filed two applications in this field [70,71]. In these patents, the preferred compounds with benzodiazepine or pyridazine scaffold (Figure 4) showed an $\mathrm{EC}_{50}$ that induced greater than $5 \%$ potentiation of the GABA-evoked chlorine current, showing a strong positive allosteric modulatory effect on the $\alpha 5 \mathrm{GABA}_{\mathrm{A}}$-Rs.

\subsection{Selective $\alpha 2 / \alpha 3 \mathrm{GABA}_{\mathrm{A}}$ agonists}

A series of cinnoline and fused quinoline derivatives have been claimed by Astrazeneca $\mathrm{AB}$ as $\mathrm{GABA}_{\mathrm{A}}-\mathrm{R}$ modulators [72-75]. The inventions disclosed derivatives able to module the function and activity of GABA and $\mathrm{GABA}_{\mathrm{A}}$-Rs in mammalian subjects, to treat anxiety disorders, cognitive disorders associated with mood and schizophrenia. The therapeutic effect of certain compounds as $\alpha 2 / \alpha 3 \mathrm{GABA}_{\mathrm{A}}$ agonists, in the cognitive impairment associated with schizophrenia, may be demonstrated by using the EEG protocol. These compounds attenuated the high-frequency EEG deficits present in schizophrenic patients. In these international applications, [72-75], $\mathrm{GABA}_{\mathrm{A}}-\mathrm{R}$ binding assay was performed as reported in Table 4 .

A patent application from the Zurich University [76] reported to the use of $\alpha 2 / \alpha 3 \mathrm{GABA}_{\mathrm{A}}$ agonists or partial agonists for the treatment of neuropathic pain. In vivo tests to assess the sensitivity to tonic nociceptive stimulation (formalin test) and the pro- or antinociceptive effect in the chronic constriction injury (CCI) model were reported for selected known 
<smiles>CCOC(=O)c1ncn2c1Cn1nnc(CC)c1-c1cc(OC)ccc1-2</smiles>

Compound 7

WO2012068149 [70]

GABA $\alpha 5 \mathrm{EC}_{50} \%$ potentiation $=11.1$<smiles>[R]c1c(-c2ccccc2)cnnc1-c1cccc(Br)c1</smiles>

Compound 4

WO2012068161 [71]

GABA $\alpha 5 \mathrm{EC}_{50} \%$ potentiation $=42$<smiles>CC(=O)c1coc(-c2c(-c3ccccc3)cnnc2-c2cccc(Cl)c2)n1</smiles>

Compound 27 WO2012068161 [71]

GABA $\alpha 5 \mathrm{EC}_{50} \%$ potentiation $=30.5$

Figure 4. Examples of compounds claimed by Agenebio, Inc.

Table 4. A list of the patents and representative compounds (Astrazeneca AB).

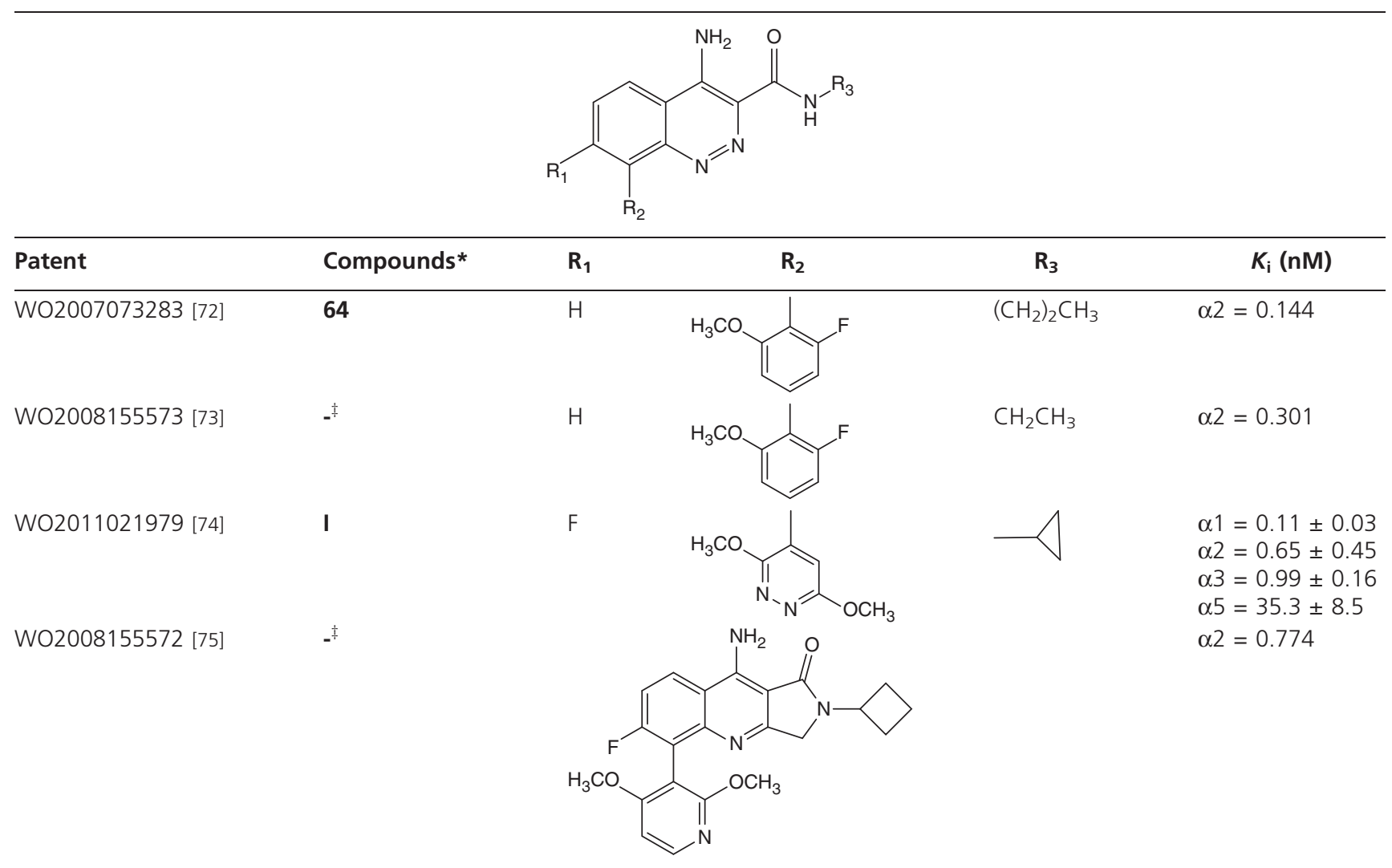

*Original number compound used in the cited patents: selection, made by the authors, of the most representative structures. ${ }^{\ddagger}$ Number not reported. 
<smiles>Cn1ncnc1COc1nn2c(-c3cc(F)ccc3F)nnc2cc1C(C)(C)C</smiles>

L838417<smiles>CCn1ncnc1COc1nn2c(-c3ccccc3F)nnc2cc1C(C)(C)C</smiles>

TPA023<smiles>Cc1nnc2ccc(-c3cccc(C(F)(F)F)c3)nn12</smiles>

CL218872

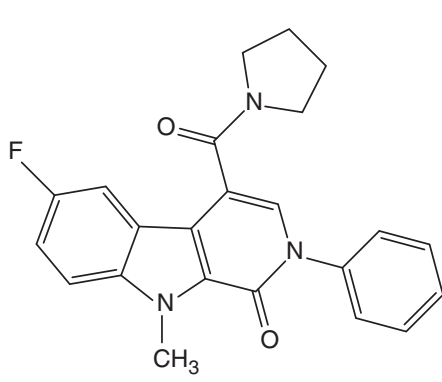

SL651498<smiles>O=C(c1ccccn1)c1cnn2c(-c3ccncc3)ccnc12</smiles>

Ocinaplon

WO2006061428 (Universitat Zurich) [76]

Figure 5. Examples of compounds claimed by Universitat Zurich.

Table 5. A list of the patents and representative compounds (Cook and Wisys).

\begin{tabular}{|c|c|c|c|c|c|c|c|}
\hline \multirow[t]{2}{*}{ Patent } & \multirow[t]{2}{*}{ Compounds } & \multirow[t]{2}{*}{$\mathbf{R}$} & \multirow[t]{2}{*}{$x$} & \multicolumn{4}{|c|}{$K_{\mathrm{i}}(\mathrm{nM})$} \\
\hline & & & & $\alpha 1$ & $\alpha 2$ & $\alpha 3$ & $\alpha 5$ \\
\hline \multirow[t]{3}{*}{ US2010317619 [77] } & XHe-II-53 & $\mathrm{H}$ & $\mathrm{CH}$ & 287 & 45 & 96 & 138 \\
\hline & JY-XHe-053 & $\mathrm{H}$ & $C F$ & 21.99 & 12.34 & 34.9 & 0.671 \\
\hline & HZ166 & $\mathrm{H}$ & $\mathrm{N}$ & 118 & 148 & 365 & 76.88 \\
\hline US7618958 [78] & $\mathrm{SH}-053-s-\mathrm{CH}_{3}$ & $\mathrm{CH}_{3}$ & $\mathrm{CH}$ & \multicolumn{4}{|c|}{$\begin{array}{l}\text { Anxiolytic activity without suppressing locomotor } \\
\text { activity } 56-100 \mathrm{mg} / \mathrm{kg}\end{array}$} \\
\hline
\end{tabular}

compounds, L838417, TPA023, CL218872, SL651498, Ocinaplon $(10 \mathrm{mg} / \mathrm{kg}$ p.o.) versus diazepam $(0.09 \mathrm{mg} / \mathrm{kg}$ i.t. or $10 \mathrm{mg} / \mathrm{kg}$ p.o.) (Figure 5). For some of these compounds, detailed information is available in the references cited in the same patent and in the recent literature [21].
James Cook and Wisys Technology Foundation have patented [77,78] a series of compounds with benzodiazepine scaffold fused with a heterocyclic five-membered ring (Table 5), with selective agonist efficacy at $\mathrm{GABA}_{\mathrm{A}} \alpha 2 / \alpha 3$ in comparison with $\alpha 1$, despite the high affinity to all subtype receptors. 
Table 6. A list of the patents and representative compounds (Ferrer Internacional SA).

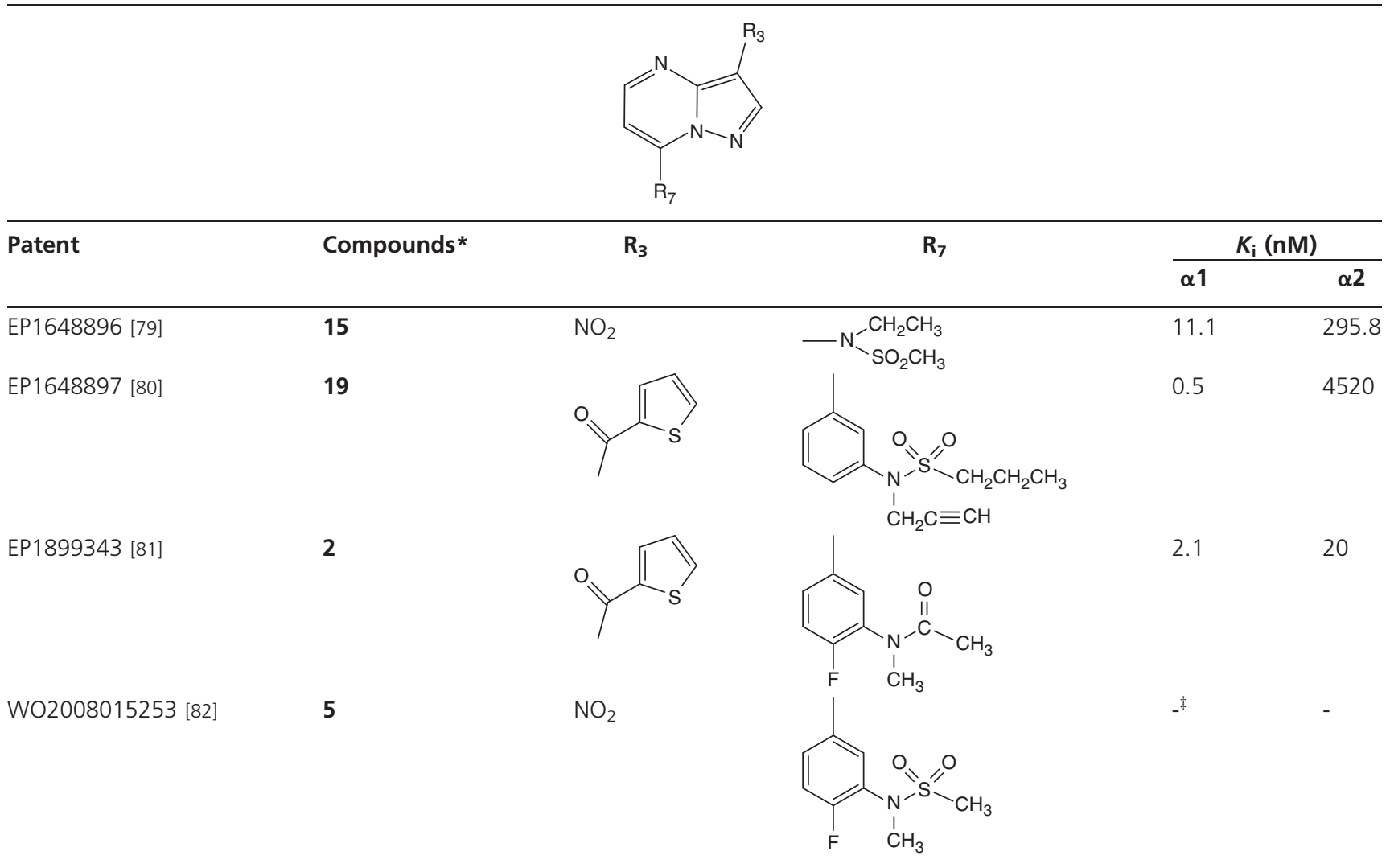

* Original number compound used in the cited patents: selection, made by the authors, of the most representative structures.

${ }^{\ddagger}$ Only specific binding, expressed as $\%$ inhibition, is reported $\left(98.2 \%\right.$ at $\left.10^{-5} \mathrm{M}\right)$. No IC 50 or $K_{\mathrm{i}}$ values are reported.

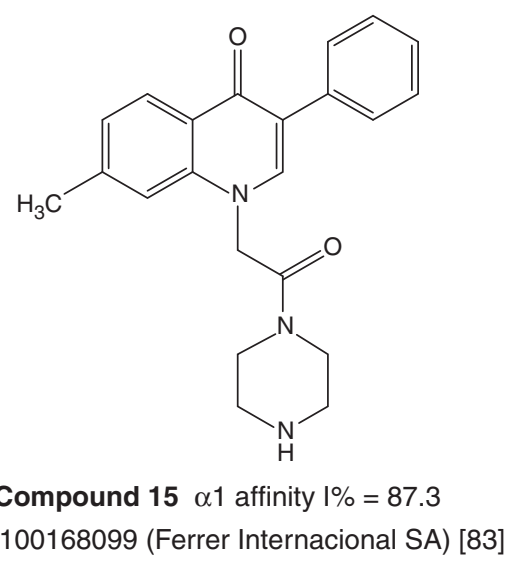

Figure 6. Examples of known compounds claimed by Ferrer Internacional SA.

Cook and co-workers reported in a US application [77] methods for suppression, alleviation and prevention of the neuropathic and inflammatory pain. Preferred compounds (XHeII-53, JY-XHe-053, and HZ166) were tested (8 - $150 \mathrm{mg} / \mathrm{kg})$ for the ability to suppress the pain (thermal hyperalgesia and mechanical sensitivity) in the chronic constriction injury (CCI) and the inflammatory pain with the formalin test models. The ability of these compounds to suppress pain with minimal ataxic and sedative effects is reflecting their selectivity for $\alpha 2$ or $\alpha 3$ compared to $\alpha 1$.

For the treatment of anxiety, Wisys Technology Foundation has patented [78] a series of compounds tested in a rodent model of anxiety and locomotor activity. The compound $\mathrm{SH}-053-s-\mathrm{CH}_{3}$ showed anxiolytic activity without suppressing locomotors activity from 56 until to $100 \mathrm{mg} / \mathrm{kg}$.

\subsection{Selective $\alpha 1 \mathrm{GABA}_{\mathrm{A}}$ agonists}

A series of patents claiming several bicyclic heteroaromatic compounds with pyrazolopyrimidine, imidazopyrimidine, imidazopyridine, imidazopyridazine and quinolone scaffolds were registered by Ferrer Internacional S.A. [79-87]. The inventions describe novel classes of subtype-selective $\alpha 1$ relative to $\alpha 2 \mathrm{GABA}_{\mathrm{A}}-\mathrm{R}$ ligands, useful in the treatment and prevention of sleep disorders, insomnia and epilepsy. Many of the novel compounds with pyrazolopyrimidine scaffold (Table 6) [79-82] and the quinolone derivatives (Figure 6) [83] were evaluated in vitro and in vivo. Good $\alpha 1$ affinity values were evidenced and the in vivo effects were assessed by predictive sedation-hypnosis tests in 
<smiles>CCC(C)N(C)c1ccc(C(=O)N(C)c2c(-c3ccc(C)cc3)nc3ccc(C)cn23)cc1</smiles>

$\alpha 1$ affinity: $1 \% 84.810^{-5} \mathrm{M}$ $\alpha 2$ affinity: $1 \% 9.410^{-5} \mathrm{M}$<smiles>CCN(c1cccc(-c2ccnc3c(C#N)ncn23)c1)S(C)(=O)=O</smiles>

Ex 5 $\alpha 1$ affinity: $1 \% 97.610^{-5} \mathrm{M}$ $\alpha 2$ affinity: $1 \% 4810^{-5} \mathrm{M}$ WO20060084835 [86]<smiles>Cc1ccc(-c2nc3ccc(C)cn3c2CC(=O)N(C)N)cc1</smiles>

Ex 6

$\alpha 1$ affinity: $1 \% 99.010^{-5} \mathrm{M}$ $\alpha 2$ affinity: $1 \% 71.610^{-5} \mathrm{M}$

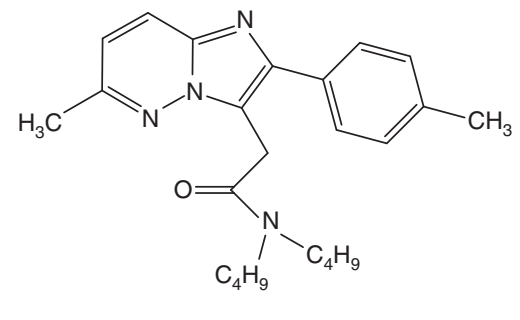

Ex 6

$\alpha 1$ affinity: $1 \% 10010^{-5} \mathrm{M}$

$\alpha 2$ affinity: $1 \% 86.610^{-5} \mathrm{M}$

WO2007110437 [87]

Figure 7. Examples of compounds claimed by Ferrer Internacional SA.

mice (expressed as percentage of crossings of treated animals versus controls, $89-95 \%$ ) with respect to the reference compound zaleplon (84.9\%).

As concerning the imidazole derivatives (Figure 7) in which the heterocyclic ring is variously fused with pyridine, pyrimidine and pyridazine moieties, the in vitro and in vivo tests were reported in four patents [84-87]. Certain compounds exhibited high selectivity for the $\alpha 1 \mathrm{GABA}_{\mathrm{A}}$ subtype receptors with respect to the $\alpha 2$ ones, suggesting their possible use in diseases or conditions in which preferential activity on the $\alpha 1$ receptors is desirable, such as insomnia, anesthesia, induction of sleep and sedation. Affinity data were expressed as percentage inhibition (I\%) at $10^{-5}$ for $\alpha 1$ and for $\alpha 2$ subunits and the percentage inhibition of motor activity was in the $85-92 \%$ range.

\section{3. $\mathrm{GABA}_{\mathrm{A}}$ receptor modulators}

Many companies and institutions reported in several patents on ligands binding to the $\mathrm{GABA}_{\mathrm{A}} / \mathrm{Bz}$ site that could be used in the treatment and/or prevention of a variety of disorders of the central nervous system in particular in anxiety and related diseases. In vitro inhibition of ${ }^{3} \mathrm{H}$-flunitrazepam $\left({ }^{3} \mathrm{H}-\mathrm{FNM}\right)$ binding was performed and the affinity value of the tested substance, which inhibits the specific binding of ${ }^{3} \mathrm{H}$ FNM by $50 \%$, was given as $\mathrm{IC}_{50}$ or $K_{\mathrm{i}}$ values. All reported compounds may be also useful in their labeled form as radiotracers for positron emission tomography (PET) imaging or for single photon emission computerized tomography (SPECT).

Neurosearch has filed a series of 17 [88-104] patents concerning novel benzimidazole derivatives (Table 7) and 4 patents [105-108] describing imidazole derivatives (Table 8), active from the submicromolar to the picomolar range $\left(\mathrm{IC}_{50}\right.$ $0.10-0.00029 \mu \mathrm{M})$.

Neurogen published 11 patents and/or applications [109-119] in which are reported numerous heterocyclic compounds (around 2400 derivatives) exhibiting $K_{\mathrm{i}}$ values in the range of $1 \mu \mathrm{M}-10 \mathrm{nM}$. To rationalize all these compounds we have summarized the most representative chemical scaffolds and structures in Figures 8, 9 [109,116-119], in Table 9 [110,113-115,120], Table 10 [111] and Table 11 [112]. In Table 9, for the sake of simplicity, we also report the structures described by Yuelian, in the patent 


\section{G. Guerrini \& G. Ciciani}

Table 7. A list of the patents and representative compounds (Neurosearch).

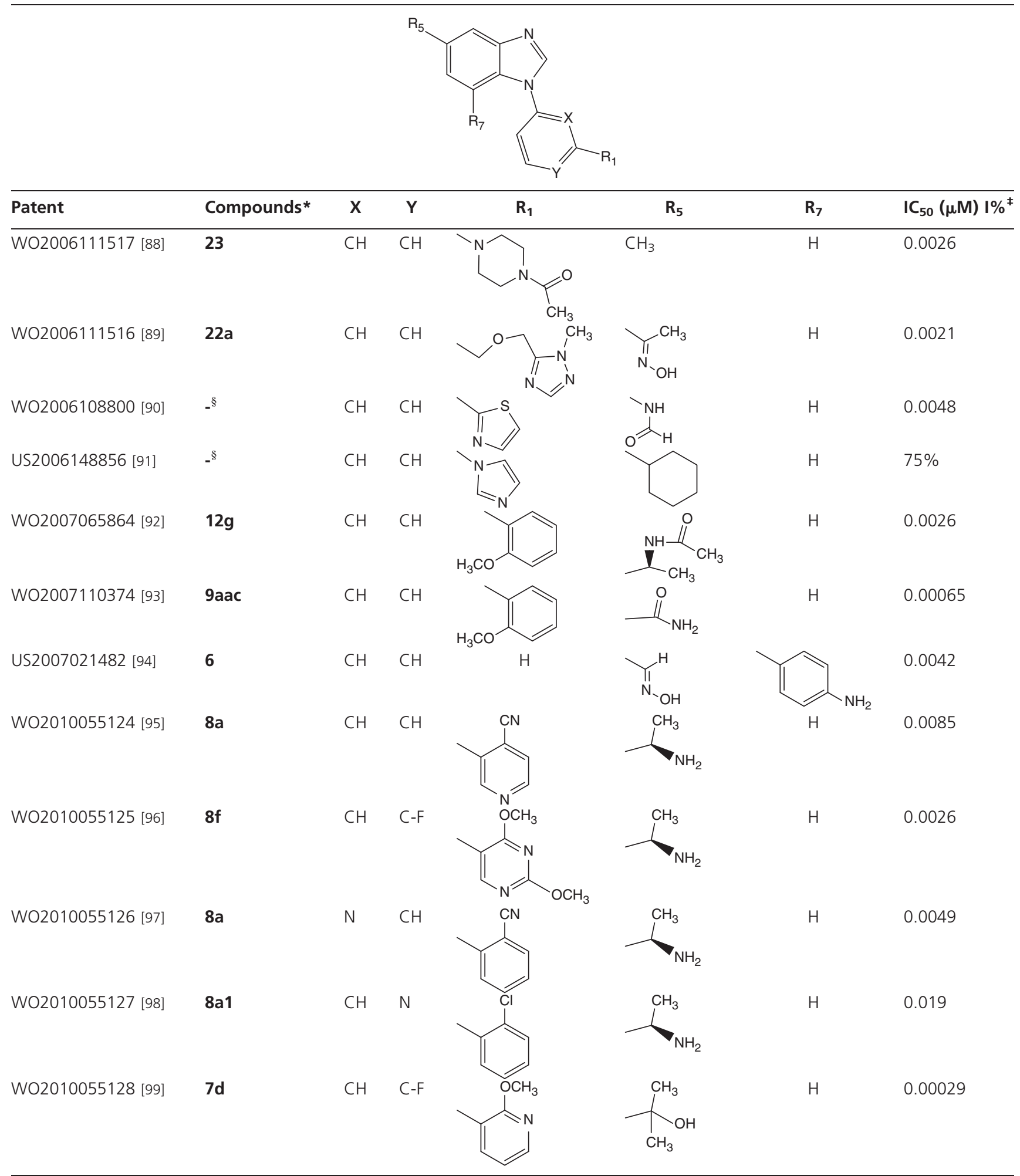

*Original number compound used in the cited patents: selection, made by the authors, of the most representative structures. ${ }^{\ddagger}$ Specific binding (I\%) must be obtained, before calculation of $\mathrm{IC}_{50}$.

${ }^{\S}$ Number not reported. 
Table 7. A list of the patents and representative compounds (Neurosearch) (continued).

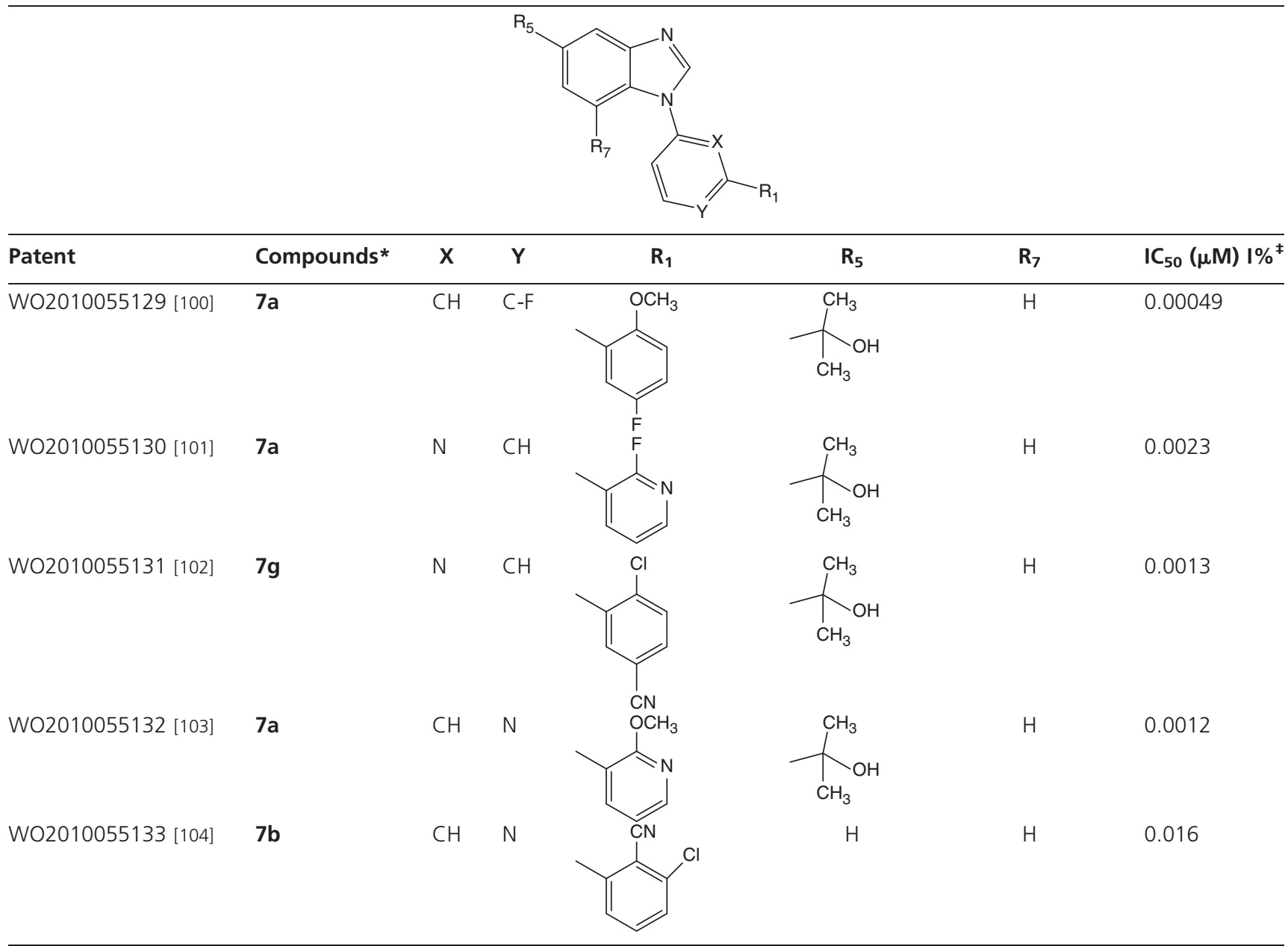

*Original number compound used in the cited patents: selection, made by the authors, of the most representative structures. ${ }^{\ddagger}$ Specific binding $(\mathrm{I} \%)$ must be obtained, before calculation of $\mathrm{IC}_{50}$.

${ }^{\S}$ Number not reported.

application [120] because of the similarity of the nucleus. Preferred compounds of this inventions exhibited $K_{\mathrm{i}}<100 \mathrm{nM}$ and the most preferred ones had $K_{\mathrm{i}}$ values $<10 \mathrm{nM}$. In Table 11 we report three compounds and the most representative general structures chosen among the numerous derivatives reported in the considered patent [112].

Helicon filed patent applications on pyrazoloquinolines [121,122], pyrazolonaphthyridines [123], and dipyrazolopyridines [124]. General binding data are reported and expressed as percentage of inhibition (I\%) (Table 12).

A series of quinolone derivatives fused with isothiazole and/ or isoxazole rings were registered by Forskarpatent I Syd $A B$ [125] together with their binding mode in a pharmacophoric model. The affinity for $\mathrm{GABA}_{\mathrm{A}} / \mathrm{Bz}$ (rat cortical membranes) was also measured. The $K_{\mathrm{i}}$ range of these novel compounds was of $1.9-18 \mathrm{nM}$ and the company claimed a method for treating anxiolytic, anticonvulsant, sedative- hypnotic, and myorelaxant conditions in mammalians, including humans (Figure 10).

\section{Labeled compounds}

Concert Pharmaceutical, Inc. patented the deuterated form of several known compounds, since they show a higher metabolic stability but a comparable pharmacological activity with respect to non-deuterated analogs. The determination of metabolic stability was performed in vitro, evaluating the "percentage parent remaining" (\% PR) that refers to the percentage of starting material remaining at a specified time point (i.e., $30 \mathrm{~min}$ ). Concert Pharm., in the field of $\mathrm{GABA}_{\mathrm{A}}$ ligands seems to be a newcomer and filed five patents [126-130] in which reported several deuterated analogs in the "various possible position" of the considered structures. The deuterated analogs of TPA023 ( $\alpha 1$ antagonist; $\alpha 2 / \alpha 3$ partial 
Table 8. A list of the patents and representative compounds (Neurosearch).

\begin{tabular}{|c|c|c|c|c|}
\hline Patent & Compounds* & $\mathbf{R}_{\mathbf{1}}$ & $\mathbf{R}_{\mathbf{2}}$ & $I C_{50}(\mu \mathrm{M}){ }^{\ddagger}$ \\
\hline WO2007042543 [105] & $-\S$ & & $\mathrm{CN}$ & 0.10 \\
\hline WO2007042544 [106] & $-\S$ & & & 0.017 \\
\hline WO2007042545 [107] & $11 a$ & & & 0.024 \\
\hline WO20070472546 [108] & 14 & & & 0.0027 \\
\hline
\end{tabular}

*Original number compound used in the cited patents: selection, made by the authors, of the most representative structures.

FSpecific binding (I\%) must be obtained, before calculation of $I C_{50}$.

${ }^{\S}$ Number not reported.<smiles>[R]c1nc2cc(Cc3[Y]cnc3-c3ccccc3Br)cnn2n1</smiles>

WO2006093911 [109] (Neurogen)

$$
\mathrm{R}=\text { alkyl; } \mathrm{R}_{1}=\mathrm{CN}, \mathrm{F} ; \mathrm{X}=\mathrm{S}, \mathrm{O}
$$

$$
K_{\mathrm{i}}<1 \mu \mathrm{M}
$$

Figure 8. Example of compound claimed by Neurogen.

agonist), NS11394 ( $\alpha 3$ agonist), $\alpha$ IA ( $\alpha 5$ inverse agonist) L838417 ( $\alpha 1$ antagonist; $\alpha 2 / \alpha 3 / \alpha 5$ agonist), and pagoclone ( $\alpha 3$ full agonist; $\alpha 1 / \alpha 2$ /and $\alpha 5$ partial agonist) are shown in Figure 11.

An important aspect developed by GE Healthcare Ltd is related to compounds useful for in vitro diagnostics and in vivo imaging of the $\mathrm{GABA}_{\mathrm{A}}$ - Rs. In particular, these inventions [131,132] deal with quinoline and carboline derivatives showing $K_{\mathrm{i}}$ value $\leq 20 \mathrm{nM}$ at the $\mathrm{GABA}_{\mathrm{A}} / \mathrm{Bz}$ site from rat cerebellar membranes. It was claimed that these novel compounds may be prepared with a detectable label, for example, ${ }^{18} \mathrm{~F}$ for PET or SPECT imaging methods. In Figure 12 are reported the only two labeled synthesized compounds claimed in this patent.

\section{Patents of natural products and derivatives}

Wien University has filed a patent application [133] for piperine derivatives as new anxiolytics with significantly reduced sedative properties without affect transient receptor potential vanilloid 1 (TRPV1). SCT-64 (ex 35) and SCT-66 (ex 36) (Figure 13) show dose-dependent anxiolytic activity at $0.3-10 \mathrm{mg} / \mathrm{kg}$ in elevated plus maze (EPM) test.

\section{Expert opinion}

This review presents an overview of the most interesting $\mathrm{GABA}_{\mathrm{A}}-\mathrm{R}$ modulators patented starting with 2006 till the present period, and can be considered an update of the previously published reviews [134,135].

The Bz-binding site on $\mathrm{GABA}_{\mathrm{A}}-\mathrm{R}$ has historically received much attention and since 1980 century many efforts were made to develop a pharmacophore/receptor model for agonists, antagonists and inverse agonists, by using a variety of 


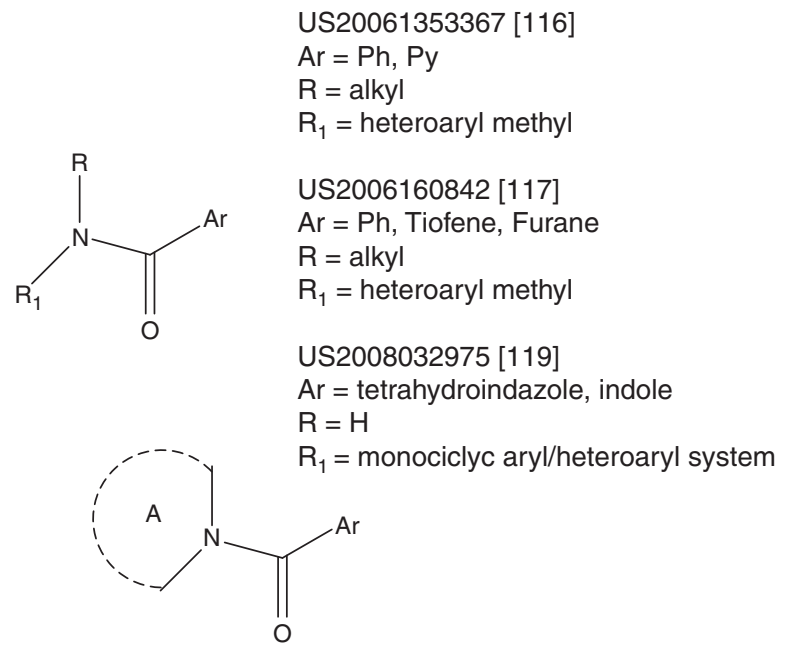

US2008146546 [118]

$\mathrm{Ar}=$ heteroaromatic bicyclic system

$\mathrm{A}=$ piperidine, pirrolidine, morfoline

Figure 9. Other compounds claimed by Neurogen.

Table 9. A list of the patents and representative compounds (Neurogen and Xu Yuelian).

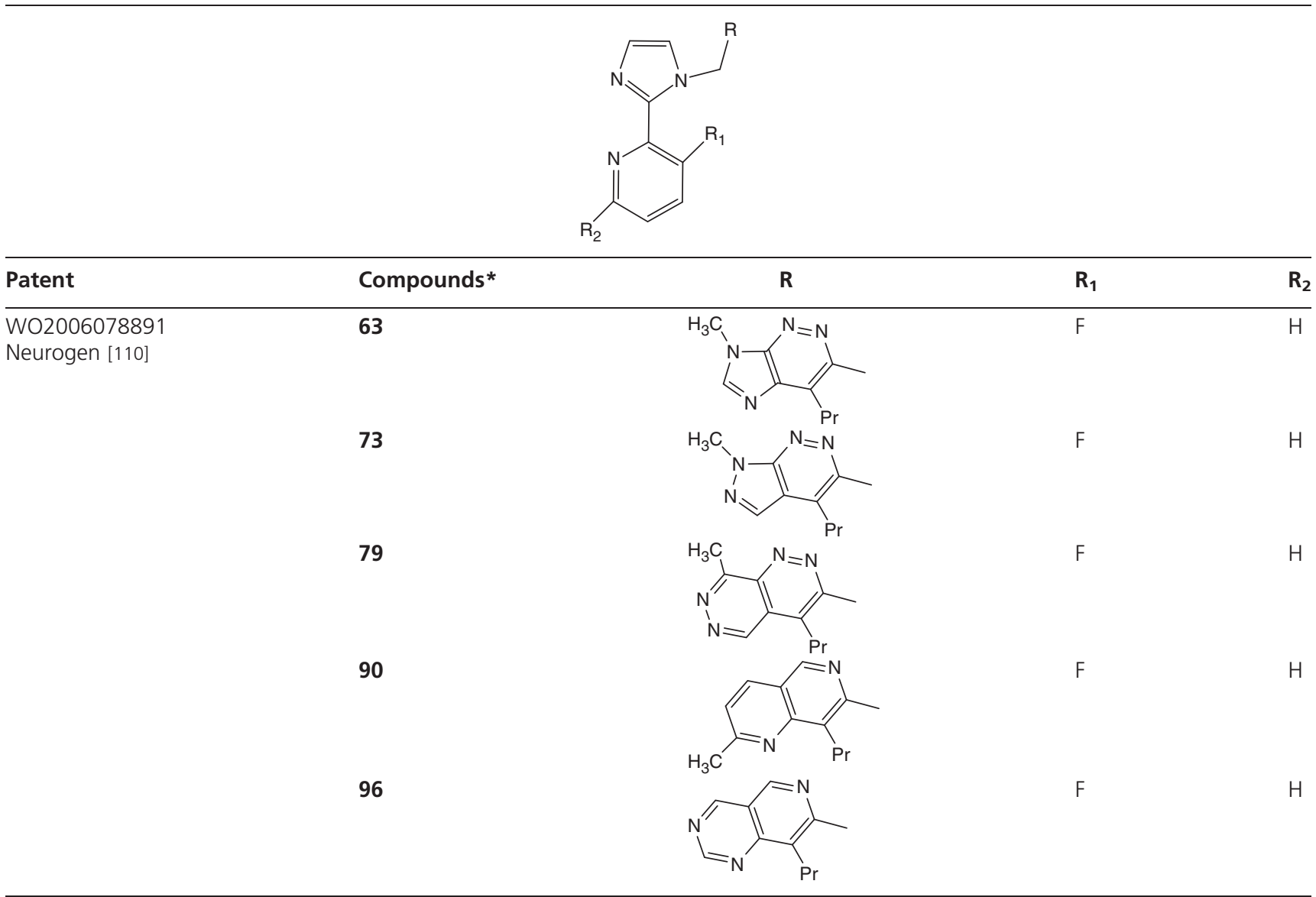

*Original number compound used in the cited patents: selection, made by the authors, of the most representative structures. 


\section{G. Guerrini \& G. Ciciani}

Table 9. A list of the patents and representative compounds (Neurogen and Xu Yuelian) (continued).

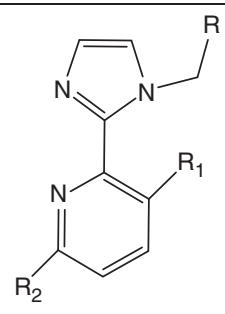

\begin{tabular}{|c|c|c|c|c|}
\hline Patent & Compounds* & $\mathbf{R}$ & $\mathbf{R}_{\mathbf{1}}$ & $\mathbf{R}_{\mathbf{2}}$ \\
\hline & 102 & & $\mathrm{~F}$ & $\mathrm{H}$ \\
\hline \multirow{3}{*}{$\begin{array}{l}\text { US2006247245 } \\
\text { Xu Yuelian [120] }\end{array}$} & Ex 5 & & $\mathrm{~F}$ & $\mathrm{H}$ \\
\hline & Ex 7 & & $\mathrm{H}$ & $\mathrm{H}$ \\
\hline & Ex 9 & & $\mathrm{~F}$ & $\mathrm{H}$ \\
\hline \multirow{3}{*}{$\begin{array}{l}\text { EP1880998 } \\
\text { Neurogen [113] }\end{array}$} & 106 & & $\mathrm{H}$ & $\mathrm{F}$ \\
\hline & 130 & & $\mathrm{~F}$ & $\mathrm{H}$ \\
\hline & 186 & & $\mathrm{~F}$ & $\mathrm{H}$ \\
\hline US7271170 & 213 & & $\mathrm{H}$ & $\mathrm{F}$ \\
\hline \multirow{3}{*}{$\begin{array}{l}\text { US20090023737 } \\
\text { Neurogen [115] }\end{array}$} & 111 & & $\mathrm{H}$ & $\mathrm{F}$ \\
\hline & 126 & & $\mathrm{H}$ & $\mathrm{F}$ \\
\hline & 128 & & $\mathrm{H}$ & $\mathrm{F}$ \\
\hline
\end{tabular}

*Original number compound used in the cited patents: selection, made by the authors, of the most representative structures. 
Table 10. A list of the patents and representative compounds (Neurogen).

\begin{tabular}{|c|c|c|c|}
\hline Patent & Compounds* & $\mathbf{R}$ & $\mathbf{R}_{\mathbf{1}}$ \\
\hline WO2006052546 [111] & $\begin{array}{l}106 \\
125 \\
215 \\
217 \\
307\end{array}$ & & $\begin{array}{l}F \\
F \\
F\end{array}$ \\
\hline
\end{tabular}

*Original number compound used in the cited patents: selection, made by the authors, of the most representative structures.

Table 11. A list of the patents and representative compounds (Neurogen).

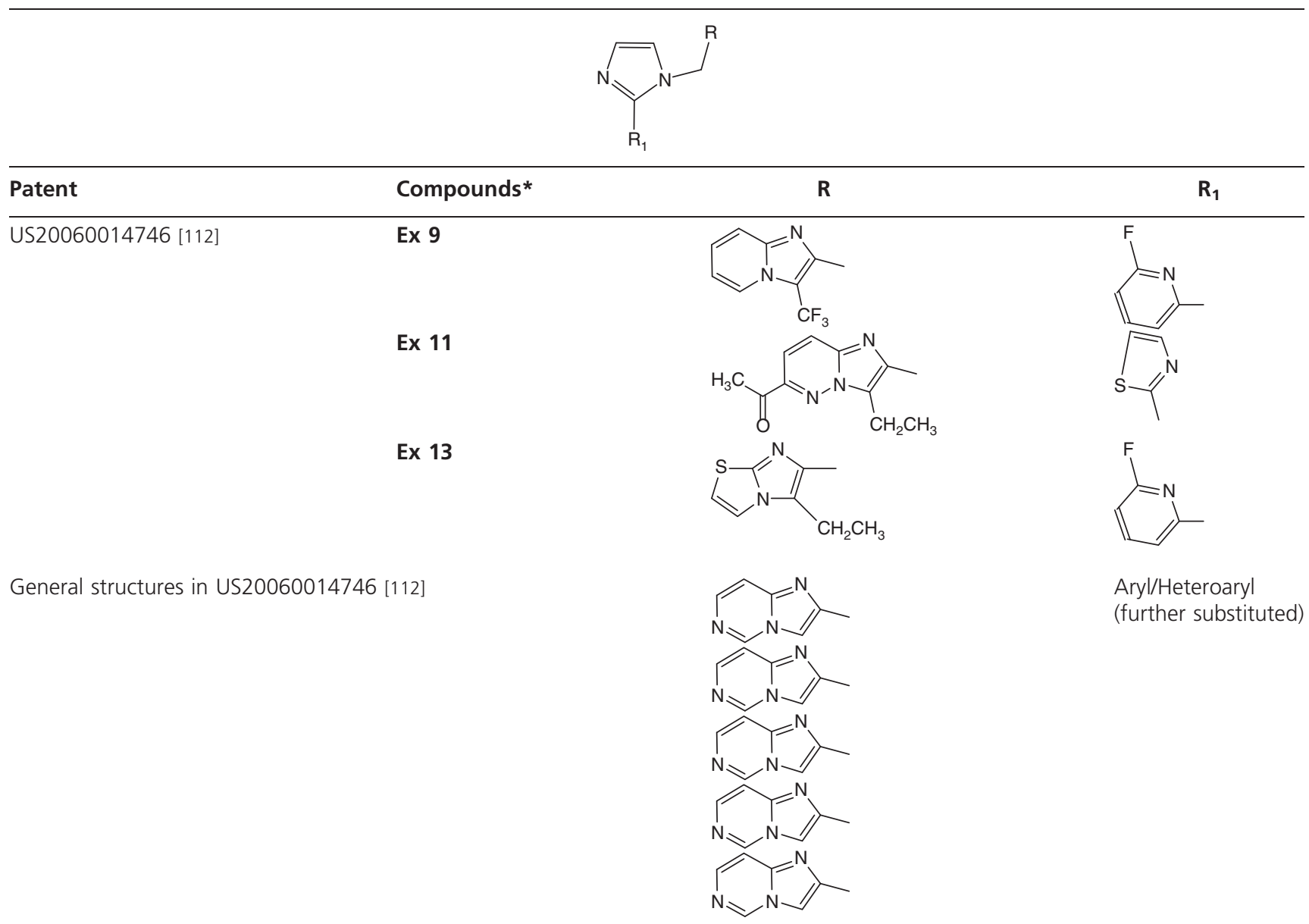


Table 12. A list of the patents and representative compounds (Helicon).

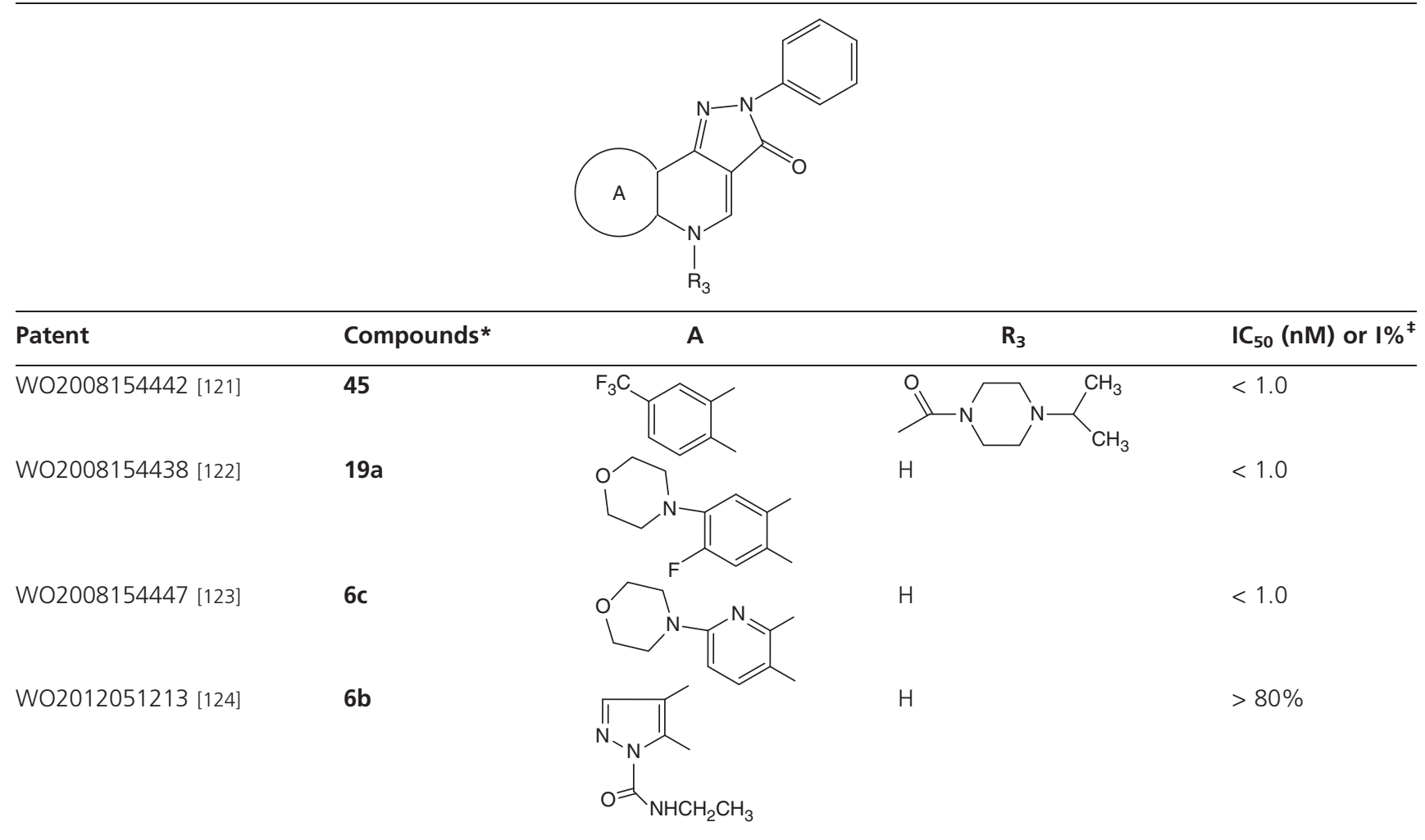

*Original number compound used in the cited patents: selection, made by the authors, of the most representative structures.

${ }^{\ddagger}$ Specific binding must be obtained, before calculation of $\mathrm{IC}_{50}$.

I\%: Percentage of inhibition at $0.1 \mu \mathrm{M}$.<smiles>[R]c1n[X]c2[nH]c3ccc(Br)cc3c(=O)c12</smiles>

WO2009123536 [125] (Forskapatent I Syd AB)

$$
\mathrm{X}=\mathrm{S}, \mathrm{O}
$$$$
\mathrm{R}_{1}=\mathrm{H}, \mathrm{CH}_{3}, \mathrm{OCH}_{3}, \mathrm{NO}_{2}, \mathrm{Br}, \mathrm{C}_{2} \mathrm{H}_{5}, \mathrm{C}_{3} \mathrm{H}_{7} \text {, }
$$$$
\mathrm{R}_{2}=\mathrm{PhCH}_{3}, \mathrm{PhBr}, \mathrm{NHCOCH}_{3}
$$

$K_{\mathrm{i}}$ range $1.9-18 \mathrm{nM}$

Figure 10. Examples of compounds claimed by Forskapatent I Syd AB.

techniques (e.g., chemical synthesis, radioligand binding, and receptor mapping) affording thus Cook's model [136]. The determination of the crystal structure of water-soluble acetylcholine binding protein (AChBP) [137] has generated much interest also for the study of the $\mathrm{GABA}_{\mathrm{A}}-\mathrm{R}$, and several comparative modeling studies have been proposed for the last one $[138,139]$. At the same time the discovery of molecular genetics and pharmacological approaches permitted to elucidate the relationship between the $\alpha$-subunit and the pharmacological effect of classical benzodiazepines, and to develop selective anxiolytic, anticonvulsant, myorelaxant, sedative and promnemonic drugs. At the present it is particularly intriguing the use of the $\alpha$-subtype selective ligands as synergic compounds in multi-targeted therapy for CNS diseases.

It is interesting to highlight that the majority of the patents, in the period 2006 - 2012, have been filed by companies (e.g., Hoffmann La-Roche, Neurogen Corp., Neurosearch A/ $\mathrm{S}$, and Wisys Technology Foundation, Inc.), extensively engaged in this research field. The $\alpha$-subtype-selective ligands, developed by these companies, are claimed in the reviewed patent applications, and represent around $70 \%$ of the considered patents. Companies such as Ferrer Internacional S.A., Helicon Therapeutics, Inc., Agenebio, Inc., Astrazeneca AB, Concert Pharmaceutical, Inc., GE Healthcare Ltd, and some University, represent the remaining 30\%, and are newcomers in this field.

The structural heterogeneity of the compounds reported in the reviewed patents does not permit to individuate a pharmacophore moiety for subtype-selective ligands. The novel compounds claimed in these patents are mainly represented by heterocycles (mono- or bicyclic, eventually further substituted with other ring systems), while the previously described 
<smiles>CC(C)(C)C(c1cc2nnc(-c3ccccc3F)n2nc1OCc1ncnn1C([O-])([O-])F)([N+]([O-])([O-])[O-])[N+]([O-])([O-])[O-]</smiles>

Compound 109 (analogue of TPA023) WO2011005520 [126]<smiles>[2H]C([2H])(C)C(O)(c1ccc2c(c1)ncn2-c1cccc(-c2ccccc2C#N)c1)C(C)(C)C</smiles>

Compound 102 (analogue of NS11394) WO2011047315 [127]<smiles>[2H]c1c(-c2nnc3c4ccccc4c(OC([2H])([2H])c4cn(C(C)(C)C)nn4)nn23)noc1C([2H])([2H])O</smiles>

Compound 115 (analogue of $\alpha 5 \mathrm{IA}$ ) WO2011020044 [128]

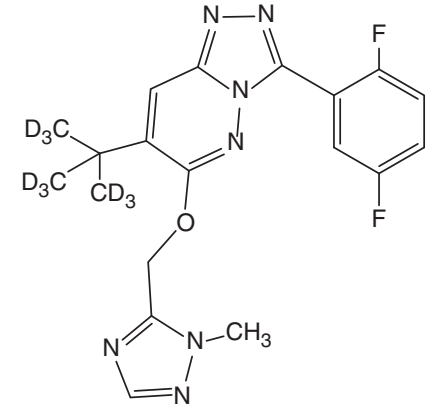

Compound 103 (analogue of L838417) WO2010025407 [129]<smiles>[2H]C([2H])([2H])C([2H])([2H])C([2H])([2H])CC(=O)C[C@H]1c2ccccc2C(=O)N1c1ccc2ccc(Cl)nc2n1</smiles>

Compound 121 (analogue of pagoclone) WO2012116288 [130]

Figure 11. Example of known compounds claimed from Concert Pharmaceutical.<smiles>O=C(NCCCF)c1cc2c(cn1)[nH]c1ccccc12</smiles>

$4\left[{ }^{18} \mathrm{~F}\right]$

WO2008132454 [131]<smiles>O=C(NCC[18F])c1c[nH]c2ccc(Cc3ccccc3)cc2c1=O</smiles>

$6 b\left[{ }^{18} \mathrm{~F}\right]$

WO2009040377 [132]

Figure 12. Examples of compounds claimed from GE Healthcare Ltd.

benzodiazepine receptor ligands showed a planar nitrogen polycyclic scaffold. Thus, a major conformational flexibility in the structure seems to be tolerated for binding on $\mathrm{GABA}_{\mathrm{A}}-\mathrm{R}$. For example Hoffmann La Roche "simplified" the rigid tetracyclic scaffold (imidazotriazolobenzodiazepine reported in the 2006 and 2007 patent applications), which led to isoxazole and triazole derivatives.
In addition to several patent applications claiming compounds acting as no-selective $\mathrm{GABA}_{\mathrm{A}}-\mathrm{R}$ modulators, most of the reviewed patents highlighted that different types of memory deficits related to AD, DS, mood disorders, schizophrenia and age-related cognitive decline, may be treated using $\alpha 5$-inverse agonists and/or $\alpha 5$-agonists. Moreover, taking into account that many neurotransmitters are involved in neurodegenerative 
<smiles>[R]N(C)C(=O)/C=C/C=C/c1ccc2c(c1)OCO2</smiles>

WO20110800313 [133] (Universitat Wien)

$$
\mathrm{R}=\mathrm{R}_{1}=n-\operatorname{Pr} \text { SCT-64 (ex 35) }
$$$$
\mathrm{R}=\mathrm{R}_{1}=i-\mathrm{Bu} \text { SCT-66 (ex 36) }
$$

\section{Figure 13. Example of compound claimed by Universitat Wien.}

diseases, the use of a dual approach (allosteric modulators of $\alpha 7-n A c h R$ and/or $\alpha 5-G A B A_{A}-R s$ ) as claimed from The Regents of the University of California, might be a therapeutically relevant modality to ameliorate CNS disorders. The enhancer cognition topic covers a wide part of the research by the drug companies, as shown by the high number of filed patents.

Another attractive aspect that stands out in this review is the use of $\alpha 2 / \alpha 3$-selective ligands for the prevention or suppression of neuropathic pain in addition to anxiolytic effects, which represents an intriguing approach, whose research is still in progress.

It is important to point out that the label strategy is another topic reported in several patents, either for improving pharmacokinetic properties without impairing pharmacodynamics properties or for generating diagnostic tools.

All these data show that since 2000 the study and development of subtype-selective receptor ligands is in progress with the aid of classic or more modern approaches. The promising aspect that arises is referred to the possibility to treat particular deficits that are not directly related to GABAergic neurotransmission.

\section{Declaration of interest}

This work was supported by a grant from the Italian Ministry for University and Research (MIUR). The authors state no conflict of interest and have received no payment in preparation of this manuscript.

\section{Bibliography}

Papers of special note have been highlighted as either of interest $(\bullet)$ or of considerable interest

$(\bullet \bullet)$ to readers.

1. Olsen RW, Sieghart W. GABAA Receptors: subtypes provide diversity of function and pharmacology. Neuropharmacology 2009;56:141-8

2. Mohler H. GABAA receptor diversity and pharmacology. Cell Tissue Res 2006;326:505-16

3. Olsen RW, Sieghart W. International union of pharmacology. LXX. subtypes of gamma-aminobutyric acid a receptors: classification on the basis of subunit composition, pharmacology and function. Update10.1124/pr.108.00505.

Pharmacol Rev 2008;60:243-60

4. Uusi-Oukari M, Korpi ER. Regulation of GABAA receptor subunit expression by pharmacological agents. Pharmacol Rev 2010;62:97-135

5. Atack JR. The benzodiazepine binding site of GABAA receptors as a target for the development of novel anxiolytics. Expert Opin Investig Drugs 2005;14:601-18

6. McKernan RM, Rosahl TW, Reynolds DS, et al. Sedative but not anxiolytic properties of benzodiazepine are mediated by the GABAA receptor al subtype. Nat Neurosci 2000;3:587-92

7. Atack JR. GABAA Receptor subtype-selective modulators. I. 2/3-
Selective agonists as non-sedating anxiolytics. Curr Top Med Chem 2011;11:1176-202

8. Atack JR. GABAA Receptor subtype-selective modulators. II. 5-selective inverse agonists for cognition enhancement. Curr Top Med Chem 2011;11:1203-14

-. A comprehensive review that describes the importance of the $\alpha 5$-Selective Inverse Agonists for

Cognition Enhancement.

9. Vinkers $\mathrm{CH}$, Mirza NR, Olivier B, Kahn RS. The inhibitory GABA system as a therapeutic target for cognitive symptoms in schizophrenia: investigational agents in the pipeline. doi:10.1517/13543784.2010.513382. Expert Opin Investig Drugs 2010;19:1217-33

10. Charych EI, Liu F, Moss SJ, Brandon NJ. GABAA receptors and their associated proteins: implications in the etiology and treatment of schizophrenia and related disorders.

Neuropharmacology

2009; In Press; Corrected Proof

11. Vollenweider I, Smith KS, Keist R, Rudolph U. Antidepressant-like properties of $\mathrm{I} \pm 2$-containing GABAA receptors. Behav Brain Res 2011;217:77-80

12. Engin E, Liu J, Rudolph U. Alpha2-containing GABAA receptors:
A target for the development of novel treatment strategies for CNS disorders. Pharmacol Ther 2012;136:142-52

13. Smith KS, Rudolph U. Anxiety and depression: mouse genetics and pharmacological approaches to the role of GABAA receptor subtypes. Neuropharmacology 2012;62:54-62

14. Zeilhofer HU, Mohler H, Di Lio A. GABAergic analgesia: new insights from mutant mice and subtype-selective agonists. Trends Pharmacol Sci 2009;30:397-402

15. Di Lio A, Benke D, Besson M, et al. HZ166, a novel GABAA receptor subtype-selective benzodiazepine site ligand, is antihyperalgesic in mouse models of inflammatory and neuropathic pain. Neuropharmacology 2011;60:626-32

16. Knabl J, Zeilhofer UB, Crestani F, et al. Genuine antihyperalgesia by systemic diazepam revealed by experiments in GABAA receptor point-mutated mice. Pain 2009;141:233-8

17. Rudolph U, Knoflach FDR. Beyond classical benzodiazepines: novel therapeutic potential of GABAA receptor subtypes. 2011;10:685-97

18. Mirza NR, Munro G. The role of GABAA receptor subtypes as analgesic targets. Drug News Perspect 2010;23:351-60 
19. Munro G, Ahring PK, Mirza NR. Developing analgesics by enhancing spinal inhibition after injury: GABAA receptor subtypes as novel targets.

Trends Pharmacol Sci 2009;30:453-9

20. Munro G, Lopez-Garcia JA,

Rivera-Arconada I, et al. Comparison of the Novel Subtype-Selective GABAA Receptor-Positive Allosteric Modulator NS11394 [3'-[5-(1-Hydroxy-1methyl-ethyl)-benzoimidazol-1-yl]-biphenyl2-carbonitrile] with Diazepam, Zolpidem, Bretazenil, and Gaboxadol in Rat Models of Inflammatory and Neuropathic Pain. J Pharmacol Exp Ther 2008;327:969-81

21. Zeilhofer HU, Benke D, Yevenes GE. Chronic pain states: pharmacological strategies to restore diminished inhibitory spinal pain control. Annu Rev Pharmacol Toxicol 2012;52:111-33

-. A comprehensive review that describes the relationship between positive allosteric modulators at $\mathrm{GABA}_{\mathrm{A}}-\mathrm{Rs}$ and pain.

22. Koh MT, Rosenzweig-Lipson S, Gallagher M. Selective GABAA alpha5 positive allosteric modulators improve cognitive function in aged rats with memory impairment. Neuropharmacology 2013;64:145-52

23. Braudeau J, Delatour B, Duchon A, et al. Specific targeting of the GABA-A receptor alpha5 subtype by a selective inverse agonist restores cognitive deficits in Down syndrome mice. J Psychopharmacol 2011;25:1030-42

24. Mohler H. Cognitive enhancement by pharmacological and behavioral interventions: the murine Down syndrome model. Biochem Pharmacol 2012;84:994-9

25. Ng HJ, Whittemore ER, Tran MB, et al. Nootropic alpha7 nicotinic receptor allosteric modulator derived from GABAA receptor modulators. Proc Nat Acad Sci USA 2007;104:8059-64

- An interesting work that describes the importance of the dual approach on $\mathrm{GABA}_{\mathrm{A}}$ receptor and nicotinic receptor.

26. Liu XF, Chang H-F, Schmiesing RJ, et al. Developing dual functional allosteric modulators of GABAA receptors. Bioorg Med Chem 2010;18:8374-82

-. An interesting work that describes the importance of the dual approach on the same $\mathrm{GABA}_{\mathrm{A}}$ receptor.
27. la Fougere C, Rominger A, Forster S, et al. PET and SPECT in epilepsy: a critical review. Epilepsy Behav 2009; $15: 50-5$

28. Hoepping A, Diekers M, Deuter-Conrad W, et al. Synthesis of fluorine substituted pyrazolopyrimidines as potential leads for the development of PET-imaging agents for the GABAA receptors. Bioorg Med Chem 2008;16:1184-94

29. Hoffmann-La Roche, Inc. Substituted imidazo[1,5-a] $[1,2,4]$ triazolo[1,5-d] $[1,4]$ benzodiazepine derivatives. US2006079507; 2006

30. Hoffmann-La Roche, Inc. Substituted imidazo[1,5-a] [1,2,4] triazolo[1,5-d] [1,4] benzodiazepine derivatives. US2006084642; 2006

31. Hoffmann-La Roche, Inc. Substituted imidazo[1,5-a] [1,2,4] triazolo[1,5-d][1,4] benzodiazepine derivatives. US2006128691; 2006

32. Hoffmann-La Roche, Inc. Halogen substituted benzodiazepine derivatives. WO2006045429; 2006

33. Hoffmann-La Roche, Inc. Imidazobenzodiazepine derivatives. WO2007042421; 2007

34. Hoffmann-La Roche, Inc. Aryl-isoxazol4-yl-imidazole derivatives. WO2007074078; 2007

35. Hoffmann-La Roche, Inc. Aryl-isoxazol4-yl-imidazo[1,2-a]pyridine useful for the treament of Alzheimer's deseases via GABA receptors. WO2007082806; 2007

36. Hoffmann-La Roche, Inc. Aryl-isoxazol4-yl-imidazo[1,5-a] pyridine derivatives. WO2007074089; 2007

37. Hoffmann-La Roche, Inc. Aryl-isoxazolo4-yl-oxadiazole derivatives. WO2007071598; 2007

38. Hoffmann-La Roche, Inc. 3-Arylisoxazole-4-carbonyl-indole derivatives. US2007105922; 2007

39. Hoffmann-La Roche, Inc. Isoxazolo derivatives. US2007066668; 2007

40. Hoffmann-La Roche, Inc. Aryl-4ethynyl-isoxazole derivatives. WO2007137954; 2007

41. Hoffmann-La Roche, Inc. Isoxazole-imidazole derivatives. WO2009000662; 2009

42. Hoffmann-La Roche, Inc. Isoxazolo-pyridine derivatives. WO2009071476; 2009
43. Hoffmann-La Roche, Inc. Isoxazolo pyridine derivatives. US2009143385; 2009

44. Hoffmann-La Roche, Inc. Isoxazolo-pyrazine derivatives. US2009143407; 2009

45. Hoffmann-La Roche, Inc. Isoxazolo-pyridazine derivatives. WO2010127968; 2010

46. Hoffmann-La Roche, Inc. Hydroxymethyl isoxazole derivatives as GABAA modulators. WO2010112475; 2010

47. Hoffmann-La Roche, Inc. Isoxazole-thiazole derivatives as GABAA receptor inverse agonist for use in the treatment of cognitive disorders. WO2010127974; 2010

48. Hoffmann-La Roche, Inc. Isoxazolo-pyrazole derivatives. WO2010127975; 2010

49. Hoffmann-La Roche, Inc. Isoxazolo-pyridine derivatives. WO2010127976; 2010

50. Hoffmann-La Roche, Inc. Isoxazolo-pyridine derivatives as GABA modulators. WO2010127978; 2010

51. Hoffmann-La Roche, Inc. Isoxazolo-pyrazine derivatives. US2010256154; 2010

52. Hoffmann-La Roche, Inc. Isoxazoles/Opyridine derivatives with ethyl and ethenyl linker. US2010216845; 2010

53. Hoffmann-La Roche, Inc. Isoxazole-isoxazoles and isoxazole-isiothiazoles. US2010210651; 2010

54. Hoffmann-La Roche, Inc. Novel triazole compounds III. WO2012076590; 2012

55. Hoffmann-La Roche, Inc. Novel triazole compounds I. WO2012062687; 2012

56. The Governing Council of the University of Toronto. Methods for the prevention and/or treatment of memory. WO2012051707; 2012

57. Atack JR, Bayley PJ, Seabrook GR, et al. L-655,708 enhances cognition in rats but is not proconvulsant at a dose selective for [alpha]5-containing GABAA receptors. Neuropharmacology 2006;51:1023-9

58. Atack JR, Maubach K, Wafford KA, et al. In vitro and in vivo properties of 3-tert-butyl-7-(5-methylisoxazol-3-yl)-2(1-methyl-1H-1,2,4-triazol-5-ylmethoxy)pyrazolo[1,5-d] $[1,2,4]$ triazine (MRK016),a GABAA Receptor alpha5 subtype 
selective inverse agonist. J Pharmacol Exp Ther 2009;331:470-84

59. Cambridge Enterprise Ltd. Use of GABAA receptor antagonists to treat cognitive impairment in patients with psychiatric conditions. WO2009016329; 2009

60. Savic MM, Obradovic DI, Ugresic ND, et al. Bidirectional effects of benzodiazepine binding site ligands in the passive avoidance tasck: differential antagonism by flumazenil and beta-CCt. Behav Brain Res 2005;158:293-300

61. Centre National de la Recherche Scientifique-CNRS. Composition and method for treating cognitive impairments in Down syndrom subject. WO2011024115; 2011

62. Knust H, Achermann G, Ballard T, et al. The discovery and unique pharmacological profile of RO4938581 and RO4882224 as potent and selective GABAA [alpha] 5 inverse agonists for the treatment of cognitive dysfunction. Bioorg Med Chem Lett 2009;19:5940-4

63. The Board of Trustees of the Leland Stanford Junior University. Cognitive function. US20121574445; 2012

64. Wisys Technology Foundation, Inc. Gabaergic agents to treat memory deficits. US7595395; 2009

65. Savic MM, Clayton T, Furtmuller R, et al. PWZ-029, a compound with moderate inverse agonist functional selectivity at GABAA receptors containing [alpha] 5 subunits, improves passive, but not active, avoidance learning in rats. Brain Res 2008;1208:150-9

66. Han D, Holger Forsterling F, Li X, et al. A study of the structure-activity relationship of GABA A-benzodiazepine receptor bivalent ligands by conformational analysis with low temperature NMR and X-ray analysis. Bioorg Med Chem 2008;16:8853-62

67. Cook James. Gabaergic agents to treat memory deficits. US2010130479; 2010

68. The Regents of the University of California. Substituted heterocycles and their use as allosteric modulators af nicotinic and GABAA receptors. WO2010104843; 2010

69. The Johns Hopkins University. Methods for characterizing and treating cognitive impairment in aging and disease. WO2007019312; 2007
70. Agenebio, Inc. Benzodiazepine derivatives, compositions and methods for treating cognitive impairment. WO2012068149; 2012

71. Agenebio, Inc. Pyridazine derivatives, compositions and methods for treating cognitive impairment. WO2012068161; 2012

72. Astrazeneca AB. Substituted cinnoline derivatives as GABAA receptor modulators and method for their synthesis. WO2007073283; 2007

73. Astrazeneca $\mathrm{AB}$. Uses of cinnoline compounds to treat schizophrenia. WO2008155573; 2008

74. Astrazeneca AB. Cinnoline compounds, their preparation, and their use. WO2011021979; 2011

75. Astrazeneca $\mathrm{AB}$. Compound and uses thereof - 848. WO2008155572; 2008

76. Universitat Zurich. Selective therapeutic agents for pain suppression. WO2006061428; 2006

77. Cook James. Selective agents for pain suppression. US2010317619; 2010

78. Wisys Technologys Foundation. Stereospecific anxiolytic and anticonvulsant agents with reduced muscle-relaxant, sedative-hgypnotic and ataxic effects. US7618958; 2009

79. Ferrer Internacional SA. N-[3-(3substituted-pyrazolo[1,5-a]pyrimidin-7-yl) phenyl]-sulfonamides, end composition, and methods related thereto. EP1648897; 2008

80. Ferrer Internacional SA. 7-Substituted 3-nitropyrazolo[1,5-a]pyrimidines. EP1648896; 2008

81. Ferrer Internacional SA. Halogenated pyrazolo[1,5-a]pyrimidines processess, uses as GABAA receptors ligands, compositions and intermediates. EP1899343; 2010

82. Ferrer Internacional SA. Pyrazolo[1,5-a] pyrimidines processess, uses and compositions. WO2008015253; 2008

83. Ferrer Internacional SA. 1H-Quinolin-4one compounds, with affinity for the GABA receptor, processes, uses and compositions. US2010168099; 2010

84. Ferrer Internacional SA. Imidazo[1,2-a] pyridine compounds, compositions, uses and methods related thereto. WO2006051063; 2006

85. Ferrer Internacional SA. Imidazo[1,2-a] pyridin-3-yl-acetic acid hydrazides, processes for their preparation and pharmaceutical uses thereof. WO2007077159; 2007

86. Ferrer Internacional SA. N-[3-Imidazo [1,5-a]pyrimidin-4-yl)phenyl]sulfonamides and $\mathrm{N}$-[3-Imidazo[1,5-a] pyrimidin-4-yl)phenyl]-carboxamides and their use as GABAA receptor modulators. WO2006084835; 2006

87. Ferrer Internacional SA. Imidazo[1,2-b] pyridazines, their processes of preparation and their use as GABA receptor ligands. WO2007110437; 2007

88. Neurosearch AS. Benzimidazole derivatives and their use for modulating the GABAA receptor complex. WO2006111517; 2006

89. Neurosearch AS. Benzimidazole derivatives and their use for modulating the GABAA receptor complex. WO2006111516; 2006

90. Neurosearch AS. Benzimidazole derivatives and their use for modulating the GABAA receptor complex. WO2006108800; 2006

91. Neurosearch AS. Benzimidazole derivatives and their use for modulating the GABAA receptor complex. WO2006148856; 2006

92. Neurosearch AS. Benzimidazole derivatives and their use for modulating the GABAA receptor complex. WO2007065864; 2007

93. Neurosearch AS. Benzimidazole derivatives and their use for modulating the GABAA receptor complex. WO2007110374; 2007

94. Neurosearch AS. 1,5,7-Trisubstituted benzimidazole derivatives and their use for modulating the GABAA receptor complex. US2007021482; 2007

95. Neurosearch AS. Benzimidazole derivatives and their use for modulating the GABAA receptor complex. WO2010055124; 2010

96. Neurosearch AS. Benzimidazole derivatives and their use for modulating the GABAA receptor complex. WO2010055125; 2010

97. Neurosearch AS. Benzimidazole derivatives and their use for modulating the GABAA receptor complex. WO2010055126; 2010

98. Neurosearch AS. Benzimidazole derivatives and their use for modulating 
the GABAA receptor complex. WO2010055127; 2010

99. Neurosearch AS. Benzimidazole derivatives and their use for modulating the GABAA receptor complex. WO2010055128; 2010

100. Neurosearch AS. Benzimidazole derivatives and their use for modulating the GABAA receptor complex. WO2010055129; 2010

101. Neurosearch AS. Benzimidazole derivatives and their use for modulating the GABAA receptor complex. WO2010055130; 2010

102. Neurosearch AS. Benzimidazole derivatives and their use for modulating the GABAA receptor complex. WO2010055131; 2010

103. Neurosearch AS. Benzimidazole derivatives and their use for modulating the GABAA receptor complex. WO2010055132; 2010

104. Neurosearch AS. Benzimidazole derivatives and their use for modulating the GABAA receptor complex. WO2010055133; 2010

105. Neurosearch AS. Imidazole derivatives and their use for modulating the GABAA receptor complex. WO2007042543; 2007

106. Neurosearch AS. Imidazole derivatives and their use for modulating the GABAA receptor complex. WO2007042544; 2007

107. Neurosearch AS. Imidazole derivatives and their use for modulating the GABAA receptor complex. WO2007042545; 2007

108. Neurosearch AS. Imidazole derivatives and their use for modulating the GABAA receptor complex. WO2007042546; 2007

109. Neurogen Corp. Thiazolylmethyl and oxazolylmethyl heteroaryl derivatives. WO2006093911; 2006

110. Neurogen Corp. Imidazolylmethyl and pyrazolylmethyl heteroaryl derivatives. WO2006078891; 2006

111. Neurogen Corp. Pyrazolylmethyl heteroaryl derivatives. WO2006052546; 2006

112. Neurogen Corp. Heteroaryl substituted fused bicyclic heteroaryl compounds as GABAA receptor ligands. US2006014746; 2006
113. Neurogen Corp. Imidazo-pyrimidines and triazolo-pyrimidines: benzodiazepine receptor ligands. EP1880998; 2008

114. Neurogen Corp. Imidazo-pyrimidines, triazolo-pyrimidines: and related benzodiazepine receptor ligands. US7271170; 2007

115. Neurogen Corp. Imidazo-pyridazines, triazolo-pyridazines and related benzodiazepine receptor ligands. US20090023737; 2009

116. Neurogen Corp. Arylacid pyrimidinyl amides, pyridazinyl methyl amides and related compounds. US20061353367; 2006

117. Neurogen Corp. Heteroaryl fused aminoalkyl imidazole derivatives: selective modulators of GABAA receptors. US2006160842; 2006

118. Neurogen Corp. Bicyclic and tricyclic heteroaromatic compounds. US2008146546; 2008

119. Neurogen Corp. Substituted fused pyrroleoximes and fused pyrazoleoxyme. US2008032975; 2008

120. Xu Yuelian. Substituted imidazopyrazine and triazolopyrazine derivatives: GABAA receptor ligands. US2006247245; 2006

121. Helicon Therapeutics, Inc. Therapeutic pyrazoloquinoline urea derivatives. WO2008154442; 2008

122. Helicon Therapeutics, Inc. Therapeutic pyrazoloquinoline derivatives. WO2008154438; 2008

123. Helicon Therapeutics, Inc. Therapeutic pyrazolonaphthyridine derivatives. WO2008154447; 2008

124. Helicon Therapeutics, Inc. Therapeutic 5,6,5-tricyclic analogs. WO2012051213; 2012

125. Forskarpatent I SYD AB. New classes of GABAA/BZR ligands. WO2009123536; 2009

126. Concert Pharmaceutical, Inc. Deuterium-modified triazolo-pyridazine derivatives as GABAA receptor modulators. WO2011005520; 2011

127. Concert Pharmaceutical, Inc. Substituted benzimidazoles. WO2011047315; 2011

128. Concert Pharmaceutical, Inc. Substituted triazolo-phthalazine derivatives. WO2011020044: 2011

129. Concert Pharmaceutical, Inc. Substituted triazolo-pyridazine derivatives. WO2010025407; 2010
130. Concert Pharmaceutical, Inc. 2-Aminonaphthiridine derivatives. WO2012116288; 2012

131. Ge Healthcare Ltd. Carbolines and their use as imaging agents. WO2008132454; 2008

132. GE Healthcare Ltd. Imaging agents. WO2009040377; 2009

133. Universitat Wien. Novel piperine derivatives as GABAA receptors modulators. WO20110800313; 2011

134. Cooke AJ, Hamilton MN. alpha-Subunit selective modulators of GABAA receptor function as CNS therapeutics. Expert Opin Ther Patent 2002;12:1491-501

135. Romanelli MN, Gualtieri F. The quest for the treatment of cognitive impairment:alpha7 nicotinic and alpha5 GABAA receptor modulators. Expert Opin Ther Patent 2007;17:1365-77

136. Zhang W, Koehler KF, Zhang P, Cook JM. Development of a comprehensive pharmacophore model for benzodiazepine receptor. Drug Des Discov 1995;12:193-248

137. Brejc K, van Dijk W, Klassen R, et al. Crystal structure of an ACh-binding protein reveals the ligand-binding domain of nicotinic receptors. Nature 2001;411:269-76

138. Ernst M, Bruckner S, Boresch S, Sieghart W. Comparative Models of GABAA Receptor Extracellular and Transmembrane Domains: important Insights in Pharmacology and Function 10.1124/mol.105.015982 Mol Pharmacol 2005;68:1291-300

139. Hanson SM, Czajkowski C. Structural mechanisms underlying benzodiazepine modulation of the GABAA receptor. J Neurosci 2008;28:3490-9

\section{Affiliation}

Gabriella Guerrini ${ }^{\dagger}$ \& Giovanna Ciciani

${ }^{\dagger}$ Author for correspondence

Researcher,

Dipartimento di Neuroscienze, Psicologia,

Area del Farmaco e Salute del Bambino,

NEUROFARBA - "Sezione di

Farmaceutica e Nutraceutica"

Università degli Studi di Firenze,

Via Ugo Schiff,6 - 50019

Sesto Fiorentino- Fi, Italy

Tel: +39055 4573766;

Fax: +39055 457 3671/3780;

E-mail: gabriella.guerrini@unifi.it 